\title{
Targeting Adrenergic Receptors in Metabolic Therapies for Heart Failure
}

\author{
Dianne M. Perez
}

check for

updates

Citation: Perez, D.M. Targeting Adrenergic Receptors in Metabolic Therapies for Heart Failure. Int. J. Mol. Sci. 2021, 22, 5783. https:// doi.org/10.3390/ijms22115783

Academic Editor: Mathias Mericskay

Received: 10 May 2021

Accepted: 22 May 2021

Published: 28 May 2021

Publisher's Note: MDPI stays neutral with regard to jurisdictional claims in published maps and institutional affiliations.

Copyright: (C) 2021 by the author. Licensee MDPI, Basel, Switzerland. This article is an open access article distributed under the terms and conditions of the Creative Commons Attribution (CC BY) license (https:// creativecommons.org/licenses/by/ $4.0 /)$.
The Lerner Research Institute, The Cleveland Clinic Foundation, 9500 Euclid Ave, Cleveland, OH 44195, USA; perezd@ccf.org; Tel.: +1-216-444-2058

\begin{abstract}
The heart has a reduced capacity to generate sufficient energy when failing, resulting in an energy-starved condition with diminished functions. Studies have identified numerous changes in metabolic pathways in the failing heart that result in reduced oxidation of both glucose and fatty acid substrates, defects in mitochondrial functions and oxidative phosphorylation, and inefficient substrate utilization for the ATP that is produced. Recent early-phase clinical studies indicate that inhibitors of fatty acid oxidation and antioxidants that target the mitochondria may improve heart function during failure by increasing compensatory glucose oxidation. Adrenergic receptors $\left(\alpha_{1}\right.$ and $\beta)$ are a key sympathetic nervous system regulator that controls cardiac function. $\beta$-AR blockers are an established treatment for heart failure and $\alpha_{1 \mathrm{~A}}-\mathrm{AR}$ agonists have potential therapeutic benefit. Besides regulating inotropy and chronotropy, $\alpha_{1}$ - and $\beta$-adrenergic receptors also regulate metabolic functions in the heart that underlie many cardiac benefits. This review will highlight recent studies that describe how adrenergic receptor-mediated metabolic pathways may be able to restore cardiac energetics to non-failing levels that may offer promising therapeutic strategies.
\end{abstract}

Keywords: adrenergic receptor; metabolism; heart; myocyte

\section{Introduction}

Adrenergic receptors (ARs) are members of the G-Protein Coupled Receptor (GPCR) superfamily that bind adrenaline (i.e., epinephrine) and noradrenaline (i.e., norepinephrine) [1] They regulate the sympathetic nervous system at both central and peripheral sites and modulate the "flight or fight" response to stress. Manifestations of this response include increasing heart rate and contractility, diverting blood flow to essential organs such as skeletal muscle and increasing metabolism to promote survival. ARs are classified into three families: $\alpha_{1}, \alpha_{2}$, and $\beta$. Each of these families contain three subtypes $\left(\alpha_{1 \mathrm{~A}}, \alpha_{1 \mathrm{~B}}, \alpha_{1 \mathrm{D}}\right)$, $\left(\alpha_{2 A}, \alpha_{2 B}, \alpha_{2 C}\right),\left(\beta_{1}, \beta_{2}\right.$, and $\left.\beta_{3}\right)$, and all three families bind epinephrine (Epi) and norepinephrine (NE) with similar affinity. However, they can regulate different physiological processes because they couple to different heterotrimeric and monomeric G-proteins and effector proteins that transduce different signaling pathways (Table 1). AR signaling causes a negative feedback to desensitize and regulate the signal transduction process through activation of GPCR kinases that phosphorylate specific residues on the receptor [2,3].

While $\beta$-ARs are well known to be affected during heart failure (HF) and $\beta$-AR blockers used in HF treatment, the role of $\alpha_{1}$-ARs, particularly the $\alpha_{1 \mathrm{~A}}$-AR, are recent developments in offering cardioprotective and inotropic benefits during HF. Their roles in regulating metabolic pathways that are altered during HF may be an underappreciated mechanism in their ability to treat HF and is the focus of this review. 
Table 1. Properties of the AR Subtypes in the Cardiovascular System.

\begin{tabular}{|c|c|c|c|}
\hline Subtype & Signal Transduction & Tissue Distribution & Physiological Function \\
\hline$\alpha_{1 \mathrm{~A}}$ & $\begin{array}{c}\mathrm{G}_{\mathrm{q}} / \mathrm{G}_{11} / \mathrm{PLC} / \mathrm{PKC} / \\
\mathrm{DAG} / \mathrm{IP} 3 / \mathrm{Ca}^{+2}\end{array}$ & $\begin{array}{c}\text { Cardiac myocyte } \\
\text { Vascular smooth muscle }\end{array}$ & $\begin{array}{l}\text { Positive inotropy, chronotropy, } \\
\text { cardiac hypertrophy, contraction } \\
\text { smooth muscle, blood pressure }\end{array}$ \\
\hline$\alpha_{1 \mathrm{~B}}$ & $\begin{array}{c}\mathrm{G}_{\mathrm{q}} / \mathrm{G}_{11} / \mathrm{PLC} / \mathrm{PKC} / \\
\mathrm{DAG} / \mathrm{IP} 3 / \mathrm{Ca}^{+2}\end{array}$ & $\begin{array}{l}\text { Cardiac myocyte } \\
\text { Vascular smooth muscle }\end{array}$ & $\begin{array}{c}\text { Negative inotropy, cardiac } \\
\text { hypertrophy, contraction smooth } \\
\text { muscle, blood pressure }\end{array}$ \\
\hline$\alpha_{1 \mathrm{D}}$ & $\begin{array}{c}\mathrm{G}_{\mathrm{q}} / \mathrm{G}_{11} / \mathrm{PLC} / \mathrm{PKC} / \\
\mathrm{DAG} / \mathrm{IP} 3 / \mathrm{Ca}^{+2}\end{array}$ & $\begin{array}{c}\text { Coronary arteries } \\
\text { Vascular smooth muscle }\end{array}$ & $\begin{array}{l}\text { Contraction smooth muscle, } \\
\text { blood pressure }\end{array}$ \\
\hline $\begin{array}{l}\alpha_{2 \mathrm{~A}} \\
\alpha_{2 \mathrm{~B}} \\
\alpha_{2 \mathrm{C}}\end{array}$ & $\begin{array}{l}\text { Gi/inhibit AC/ } \\
\text { cAMP/PKA }\end{array}$ & $\begin{array}{l}\text { Not in any cardiac tissue } \\
\text { Vascular smooth muscle }\end{array}$ & $\begin{array}{l}\text { NE release- Sympathetic } \\
\text { nerve endings }\end{array}$ \\
\hline$\beta_{1}$ & $\begin{array}{c}\text { Gs } / \mathrm{AC} / \mathrm{cAMP} / \mathrm{PKA} \\
\mathrm{Ca}^{+2} \text { channel }\end{array}$ & Cardiac myocyte & $\begin{array}{l}\text { Positive inotropy, chronotropy, } \\
\text { cardiac hypertrophy }\end{array}$ \\
\hline$\beta_{2}$ & $\begin{array}{c}\text { Gs } / \mathrm{AC} / \mathrm{cAMP} / \mathrm{PKA} \\
\mathrm{Ca}^{+2} \text { channel } \\
\mathrm{Gi} / \text { inhibit } \mathrm{AC} / \\
\mathrm{cAMP} / \mathrm{PKA}\end{array}$ & $\begin{array}{l}\text { Cardiac myocyte } \\
\text { Vascular smooth muscle }\end{array}$ & $\begin{array}{l}\text { Cardiac hypertrophy } \\
\text { Relaxation smooth muscle }\end{array}$ \\
\hline$\beta_{3}$ & $\begin{array}{c}\mathrm{Gs} / \mathrm{Gi} / \mathrm{AC} / \mathrm{cAMP} / \mathrm{PKA} \\
\mathrm{NO}\end{array}$ & Cardiac myocyte & Negative inotropy \\
\hline
\end{tabular}

$\mathrm{AC}$, adenylate cyclase; $\mathrm{Ca}^{+2}$, calcium; cAMP, cyclic adenosine monophosphate; DAG, diacylglycerol; IP3, inositol triphosphate; NE, norepinephrine; NO, nitric oxide; PKA, protein kinase A; PLC, phospholipase C.

\section{Cardiac ARs}

The myocyte expresses both $\alpha_{1}$ - and $\beta$-AR subtypes. $\beta$-ARs are predominately expressed in the myocyte, followed by the $\beta_{2}$-AR subtype [4,5] in an approximate 80:20 ratio. $\beta$-ARs are transduced by the $\mathrm{G}_{\mathrm{S}} \mathrm{G}$-protein to stimulate adenylate cyclase which produces a transient rise in the second messenger cAMP (Table 1). The main effector of CAMP is protein kinase A (PKA). The major function of $\beta$-ARs in the heart are to regulate rate and contractility in response to the sympathetic release of NE and Epi. PKA signaling mediates a positive inotropic and chronotropic response (Table 1) through the phosphorylation of cardiac calcium-handling and myofilaments that control the excitationcontraction coupling such as L-type $\mathrm{Ca}^{2+}$ channels, ryanodine receptors, phospholamban and troponin I [6-9]. The $\beta_{2}$-AR signals differently from the $\beta_{1}$-AR in the heart with the $\beta_{2}$-AR being able to switch coupling to $G_{i}$ (Table 1 ), resulting in cardioprotective effects against apoptosis [10-12] but has little effects on inotropy or chronotropy. There is a small amount ( $5 \%$ of total $\beta$-AR pool) of the $\beta_{3}$-AR in human heart. While the $\beta_{1}$-ARs regulate positive inotropy, the $\beta_{3}-\mathrm{AR}$ is postulated to regulate negative inotropy through its release of nitric oxide [13-16] (Table 1).

Of the $\alpha_{1}$-ARs, both the $\alpha_{1 \mathrm{~A}}$ and $\alpha_{1 \mathrm{~B}}$-AR but not the $\alpha_{1 \mathrm{D}}$-AR subtype is expressed in myocytes [17-19] (Table 1). The $\alpha_{1 \mathrm{D}}$-AR is expressed in vascular smooth muscle as are the other $\alpha_{1}$-AR subtypes but is more highly expressed in coronary arteries [20-22]. The $\alpha_{1 B}$-AR is expressed at higher levels in the heart than the $\alpha_{1 \mathrm{~A}}$-AR based upon radioligand binding studies in rodent and human tissues $[18,21,23]$ but represent a much overall lower density than total $\beta$-ARs. The main signaling pathway that is transduced by $\alpha_{1}$-ARs are coupled to the $G_{\mathrm{q} / 11}$ family of G-proteins. $G_{\mathrm{q} / 11}$ activates phospholipase $C \beta 1$ (PLC $\beta 1$ ) which cleaves the membrane-bound phosphatidylinositol 4,5-bisphosphate to release inositol triphosphate (IP3) and diacylglycerol (DAG) [24] (Table 1). The IP3 causes a release of intracellular calcium from the endoplasmic reticulum while DAG activates protein kinase $C$ (PKC). $\alpha_{1}$-ARs activate a positive inotropy induced from calcium sensitizing the myofibril filaments [25-27] and by phosphorylation of various cardiac proteins by PKC and/or Rho also contributing [28-31]. 
A main function of all $\alpha_{1}$-ARs is its ability to increase blood pressure via contraction of vascular smooth muscle (Table 1). However, in the heart, studies suggest that the $\alpha_{1 \mathrm{~A}^{-}}$ AR subtype mediates positive inotropy $[29,32-34]$ while the $\alpha_{1 \mathrm{~B}}$-AR regulates negative inotropy [35-39] which may act as a physiological brake to regulate the robust positive inotropy of $\beta$-ARs [40].

While the $\alpha_{2}$-ARs are not present in the myocyte, the $\alpha_{2 \mathrm{~B}}$-AR subtype does control vascular contraction and blood flow [41] while the $\alpha_{2 \mathrm{~A}}-\mathrm{AR}$ and $\alpha_{2 \mathrm{C}}-\mathrm{AR}$ subtypes are located on sympathetic nerve terminals to regulate the release of NE [42] (Table 1) and thus, can still influence the onset and progression of HF [43]. During failure, there is a chronic release of catecholamines from the sympathetic nerves and a genetic dysfunctional variant of the $\alpha_{2 C}-A R$ has been described in a human heart failure patient linked with poor prognosis [44].

\section{ARs in Heart Failure}

In HF, the sympathetic nervous system tries to compensate from the loss of contractility by causing high levels of catecholamine release, referred to as overdrive. The elevated plasma levels of NE cause $\beta_{1}$-ARs to be desensitized and downregulated by as much as $50 \%$ with $\beta_{2}$-ARs levels remaining unchanged as shown by radioligand binding studies $[4,45]$. Chronic stimulation of the $\beta_{1}$-ARs, while beneficial in the short-term for HF by increasing inotropy, long-term signaling causes necrosis and cell death due to cAMP-mediated calcium overload, so $\beta_{1}$-AR agonists are not a viable therapy [46-49]. In contrast, $\beta_{2}$-AR stimulation is thought to be cardioprotective, protecting against apoptosis $[11,50,51]$ and may improve function [51,52], but becomes more diffuse and non-compartmentalized in the myocyte during HF and may not signal properly [53]. $\beta$-AR blockers have long been used as a standard of treatment for HF [45,54-57]. Besides a direct blocking action of catecholamines, $\beta$-AR blockers also can re-sensitize the $\beta$-ARs preventing their downregulation and repopulating the myocyte cell surface [58].

$\beta_{3}$-AR stimulation has been proposed as a brake system for $\beta_{1}$ - and $\beta_{2}$-AR overstimulation during HF since they may couple to $G_{i}$ in the myocardium $[13,14]$. Besides having its own cardioprotective benefits [59], the $\beta_{3}$-AR lacks GPCR kinase recognition sites [60] and so will not become desensitized as the other $\beta$-ARs during sympathetic overdrive during HF. However, the potential use of $\beta_{3}$-AR agonists or antagonists in HF is still highly debated.

Changes in $\alpha_{1}$-AR receptor protein levels during HF are also controversial with receptor levels being either unchanged [21,61], increased [17,62-64] or decreased [65-67]. The vast variability in these studies of changes in $\alpha_{1}$-AR protein levels could be due to the severity, or degree of HF [66], the amount of sympathetic overdrive and plasma levels of catecholamines [68] or the etiology of HF (ischemic versus non-ischemic) since $\alpha_{1}$-ARs are known to increase receptor density during ischemia or low oxygen conditions [69-74].

Early assessments of $\alpha_{1}$-AR effects on the heart were first reported as secondary and minor to $\beta$-ARs [1] but with better tools available, the $\alpha_{1 \mathrm{~A}}$-AR has been shown to have a robust positive inotropic response in the human heart and remains functional during failure $[34,37,75-77]$. It is believed that $\alpha_{1 \mathrm{~A}}$-AR stimulation is adaptive in the heart and stimulation of this subtype may provide therapeutic benefit during failure [1,34]. Transgenic and knock-out $(\mathrm{KO})$ mouse models indicate that mice are protected against HF [78] or myocardial infarction [79]. The $\alpha_{1 \mathrm{~A}}$-AR selective agonist, A61603 or dabuzalgron can increase survival and prevent cardiac damage [80,81]. In contrast, stimulation of the $\alpha_{1 \mathrm{~B}}$-AR subtype is maladaptive in the heart and can lead to dilated cardiomyopathy or dysfunction [82-84], progressing to HF [85]. During HF and $\beta$-AR downregulation, the $\alpha_{1 \mathrm{~A}}-\mathrm{AR}$ 's contractile effects in the myocyte may become important in mitigating the loss of $\beta$-AR-mediated inotropy [37-39]. 


\section{Metabolic Regulation of Normal vs. Failing Heart}

The heart has the highest metabolic rate and energy requirement of all organs other than the kidney [86] and HF has often been characterized as "an engine out of fuel" [87]. To satisfy these high energy demands, the normal heart has a high degree of flexibility to metabolize various substrates to generate adenosine triphosphate (ATP) such as utilizing glucose, lactate, fatty acids, and ketone bodies. This process is tightly regulated but has a high degree of plasticity and interdependence between the substrates utilized. The pathology of HF causes alterations in the heart's ability to regulate and metabolize these substrates resulting in energy deficits that contribute to aversive outcomes and poor prognosis [88-90].

\subsection{Glucose Utilization}

Various carbohydrates such as glucose, glycogen, and lactate are used by the heart to produce ATP. Glucose is taken up by the myocyte through glucose transporters (GLUTs) GLUT1 and GLUT4 [91], then metabolized by oxidation to produce ATP, $\mathrm{CO}_{2}$, and $\mathrm{H}_{2} \mathrm{O}$. This process first entails glycolysis which does not require oxygen (i.e., anaerobic) and occurs in the cytosol. Phosphofructokinase 1 is the step that commits glucose to undergoing glycolysis [92]. If sufficient oxygen (i.e., aerobic) is present, pyruvate then enters the mitochondria and is metabolized further by the citric acid cycle or Krebs cycle and the electron transport system, producing in total 30 ATP molecules per molecule of glucose. If the heart is ischemic (i.e., lack or low oxygen levels), only 5 ATP molecules are produced, a vast difference. The oxidation of glucose is mainly regulated by the pyruvate dehydrogenase (PDH) complex. A schematic of glycolysis and glucose oxidation in the myocyte is shown in Figure 1.

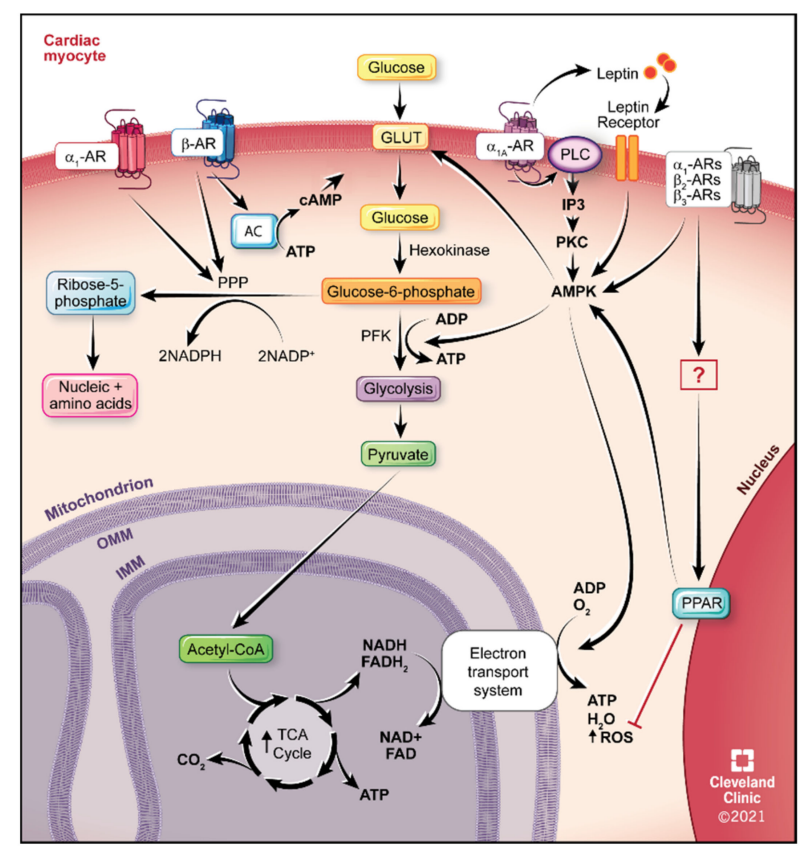

Figure 1. Adrenergic pathways that affect glucose utilization in the cardiac myocyte, showing glycolysis, glucose oxidation inside the mitochondrion, and the alternative pentose phosphate pathway (PPP). AC, adenylate cyclase; ADP, adenosine diphosphate; AMPK, AMP-activated protein kinase; $\mathrm{AR}$, adrenergic receptor; ATP, adenosine triphosphate; CoA, coenzyme A; cAMP, cyclic adenosine monophosphate; FAD, flavin adenine dinucleotide; GLUT, Glucose transporter; IMM, inner mitochondrial membrane; IP3, inositol triphosphate; OMM, outer mitochondrial membrane; PFK, phosphofructokinase; PKC, protein kinase C; PLC, phospholipase C; PPAR, peroxisome proliferatoractivated receptor; NAD, nicotinamide adenine dinucleotide; NADP, nicotinamide adenine dinucleotide phosphate; ROS, reactive oxygen species; TCA, tricarboxylic acid cycle. 
An alternative pathway for glucose utilization is the pentose phosphate pathway (PPP) which is the main generator of nicotinamide adenine dinucleotide phosphate (NADPH) in the cytoplasm [93]. It also generates ribose sugars which are used for nucleotide synthesis. The first step of the PPP is the oxidation of glucose-6-phosphate (produced through glycolysis) which uses the rate-limiting enzyme, glucose-6-phosphate dehydrogenase (G6PD) to generate NADPH (Figure 1). NADPH is required by several defensive redox antioxidant pathways for survival of the cell against reactive oxygen species (ROS), particularly in organs with high energy requirements, such as the heart [94]. In a normal heart, approximately $2-4 \%$ of oxygen used during metabolism during oxidative phosphorylation is converted to ROS [95-97]. In a healthy cell, the rate of superoxide production is kept in check by its dismutation to water and oxygen via the enzyme superoxide dismutase to hydrogen peroxide, then eventually to water $[93,98]$. An imbalance in this system can occur due to excessive ROS production or insufficient antioxidant breakdown. Increased ROS species have been well documented to occur in HF patients [99-104].

A loss of that protection from ROS damage in the heart can result from deficiency in G6PD and shown to occur during ischemia [105], and HF [105-108]. Unloading of the failing heart using a left ventricular assist device increased the metabolic flux into the PPP $[108,109]$. However, persistent activation of this pathway or upregulation of G6PD can occur during severe HF when glucose oxidation becomes severely limited and forces more of the glucose to enter the alternate PPP $[110,111]$. In this case, the PPP now promotes superoxide generation and oxidative stress in the failing heart due to increases in NADPH oxidase [112,113]. Increases in G6PD in the heart can also occur in diabetic or obese patients before cardiac pathology develops leading to more adverse outcomes [114]. The role of G6PD is even more complicated because the same study that associated deficiency and loss of ROS damage protection during HF [106] also found evidence of improvement in coronary artery disease and has been confirmed in additional studies [115,116]. Several studies on the metabolomic profiles of HF patients indicated a large array of metabolic dysfunction including the PPP $[90,91,117,118]$. The regulation of the PPP may be more important than previously realized in HF because decreased G6PD levels are the most common enzyme deficiency in humans $[119,120]$. The genetic mutation in G6PD that causes decreased expression is X-linked recessive [121], hence it is most commonly present in males and could be a possible explanation of why men developed HF more frequently than women.

\subsection{Fatty Acid Metabolism}

In the normal adult heart, about $95 \%$ of its ATP requirements are due to mitochondrial oxidative phosphorylation with $60-80 \%$ of that from fatty acid oxidation [122-126]. Fatty acids can freely cross the cell membrane or are transported and activated in the heart via transport proteins (fatty acid transport protein, FATP) and are activated by conversion to long-chain fatty acyl-CoA esters. They are then exported into the mitochondria for $\beta$-oxidation [127]. While medium chain fatty acids can cross freely into the mitochondria, a transport mechanism called the carnitine shuttle is required to shuttle long-chain fatty acids into the mitochondria using the enzymes carnitine palmitoyl transferase 1 and 2 (CPT1 and 2) $[128,129]$. Once in the mitochondria, $\beta$-oxidation begins and is cyclic, shortening the fatty acyl-CoA esters by 2 carbon units each cycle till the chain is fully broken down, liberating acetyl-CoA (which enters the TCA cycle for further metabolism), and producing nicotinamide adenine dinucleotide (NADH) and 1,5-dihydro-flavin adenine dinucleotide $\left(\mathrm{FADH}_{2}\right)$ which are oxidized in the electron transport chain (i.e., oxidative phosphorylation) to produce ATP and water. A schematic of fatty acid oxidation in the cardiac myocyte is shown in Figure 2. 


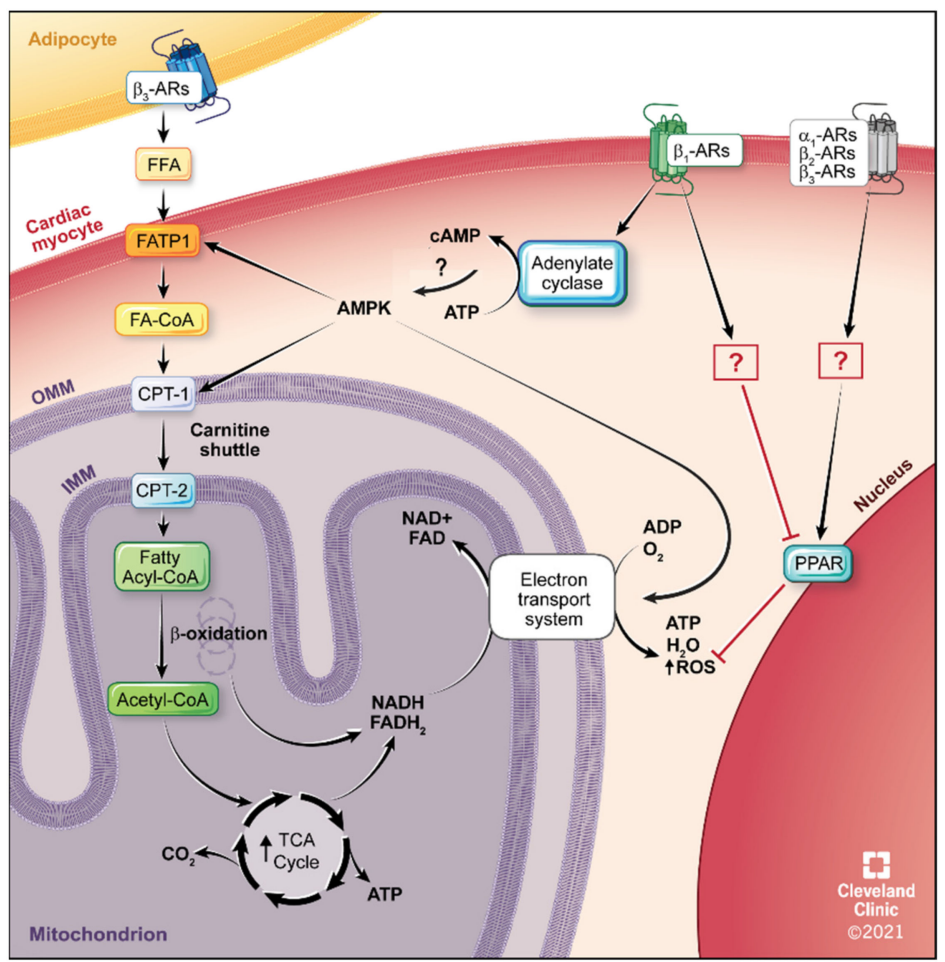

Figure 2. Adrenergic Receptor Regulation of Fatty Acid Metabolism in the Cardiac Myocyte. AC, adenylate cyclase; ADP, adenosine diphosphate; AMPK, AMP-activated protein kinase; AR, adrenergic receptor; ATP, adenosine triphosphate; CoA, coenzyme A; cAMP, cyclic adenosine monophosphate; CPT, carnitine palmitoyltransferase; FAD, flavin adenine dinucleotide; FATP1, Fatty acid transport protein 1 ; FFA, free fatty acid; IMM, inner mitochondrial membrane; NAD, nicotinamide adenine dinucleotide; OMM, outer mitochondrial membrane; PPAR, peroxisome proliferator-activated receptor; ROS, reactive oxygen species; TCA, tricarboxylic acid cycle.

As the heart fails, its ATP levels drop by $30-40 \%$ during the advanced stages of failure compared to the normal heart [130-132]. The drop in ATP production during HF is due to several factors such as increased ROS, altered calcium handling, defects in the consumption rates of oxygen, mitochondrial dysfunction, decreased electron transport chain activity, which all have effects on ATP generation during oxidative phosphorylation $[87,89,126,133-136]$. This energy deficit during HF is responsible for the loss of contractile function as contraction alone requires more than $60 \%$ of the available normal ATP pool [126]. The little ATP that is left after contraction during failure results in insufficient energy to regulate the other critical functions of the heart such as calcium handling, cellular homeostasis, and maintaining membrane potentials resulting in decrease mitochondrial turnover and biogenesis [137-141].

The metabolic profiling of induced-HF in various animal models does show considerable variability and the need to be cautious in interpretations of the early metabolic changes. During pressure overload-induced HF, there is a decrease in both fatty acid and glucose oxidation [142,143]. In other animal models of HF, such as rapid ventricular pacing, there are decreased rates of fatty acid oxidation but increased rates of glucose oxidation [110,143-145]. These differences might be due to the severity of the HF, as metabolic flexibility in substrate use that occurs in the normal heart is lost during the progression to severe HF, resulting in decreased ability to increase either fatty acid or glucose uptake $[146,147]$.

Another explanation for the metabolic disparity in the various types of HF models may be dependent upon whether there is failure with preserved ejection fraction (HFpEF) or with reduced ejection fraction (HFrEF) [148-150]. Volume or pressure overload HF models may not cause a reduction in ejection fraction. HFpEF accounts for almost half of 
the HF population but has similar morbidity and mortality rates as HFrEF [137,151-153]. In HFrEF models, the metabolic changes mostly include a decrease in both fatty acid and glucose oxidation but increases in glycolysis [144,146,149,154-156]. In contrast, in HFpEF models, fatty acid oxidation and glycolysis are increased but glucose oxidation is decreased [157-163]. As both HFrEF and HFpEF have in common a decrease in glucose oxidation resulting in cardiac energy inefficiency, metabolic treatments that can increase glucose oxidation may be the most universal in treating HF.

Abnormally high rates of glucose metabolism are one of the earliest metabolic changes that occurs during the development of HF [154,164]. The shift to increased utilization of glucose as opposed to fatty acids is postulated to occur because it spares the use of oxygen $[125,165]$. While glucose uptake is generally preserved or increased during failure, there is a metabolic shift from oxidative pathways to glycolysis and an uncoupling between glycolysis and its complete oxidation. This is because of reduced capacity to enter the TCA cycle [166] or oxidative phosphorylation due to defects in electron transport [104,167-170], resulting in energy inefficiency and functional weakening of the heart [171,172]. An increase in anaerobic glycolysis uncouples the oxidative process and results in the generation of lactate and protons [173-175]. The resulting decrease in $\mathrm{pH}$ reduces the contractility of the heart $[176,177]$ and decreases cardiac efficiency $[125,161,178,179]$. Hence, therapeutics that can optimize glucose utilization and oxidation may reduce the severity of HF by increasing energy efficiency of glucose [179-184].

\subsection{General Metabolic Therapies for HF}

Stimulating glucose uptake and oxidation in the heart has been shown to improve the rate of recovery from ischemic damage $[179,182,185,186]$. This can occur through increased GLUT expression or translocation, increased activity of phosphofructokinase 1 or flux into glycolysis $[109,110]$. However, current thinking is that increasing glucose uptake without also increasing glucose oxidation may cause an uncoupling of the pathways and lead to cardiac inefficiency [125]. Activation of pyruvate dehydrogenase (PDH), a rate-limiting enzyme in glucose oxidation, can increase glucose oxidation rates. PDK kinase inhibitors such as dichloroacetate, can stimulate PDH activity improves energy efficiency and reduces oxygen consumption to improve function during HF [187] but has a short half-life and would need to be continuously infused.

Inhibition of fatty acid oxidation causes a compensatory increase in glucose oxidation and improves cardiac metabolic efficiency, decreases mitochondrial oxidative capacity, and has also been used for a number of therapeutic strategies in HF [156]. Carnitine palmitoyltransferase-1 (CPT1) is an enzyme involved in the uptake of fatty acids into the mitochondria [188]. Inhibitors of CPT1 decrease fatty acid oxidation and increase glucose oxidation in the heart $[180,188,189]$ and can improve outcomes in HF $[190,191]$ but can lead to serious side effects and high doses cause impaired energetics [192,193]. Inhibitors of the last enzyme in fatty acid oxidation, long-chain 3-ketoacyl CoA thiolase, are showing a better therapeutic profile in treating HF [194-196].

Since fatty acid oxidation provides much greater ATP production compared with glucose, therapeutic treatments that revert the heart back to using fatty acids as substrates might also be an option for treating HF, but several models of HF have shown downregulated or have dysfunctional enzymes or proteins involved in the fatty acid oxidation process [142,197-199]. If these defects can be reversed through mechanical unloading or other means, targeting peroxisome proliferator-activated receptors (PPARs) or mitochondrial fatty acid metabolizing proteins could provide therapeutic treatments for HF.

\section{ARs in Cardiac Metabolism and as Potential Therapeutics}

ARs regulate many aspects of metabolism in the substrate preference, mobilization, and utilization as it relates to normal heart function and changes that can occur during HF $[90,117,200,201]$. Mouse embryos with dopamine $\beta$-hydroxylase gene $\mathrm{KO}$ which prevents the biosynthesis of NE or Epi, have decreased glucose metabolism, oxygen consump- 
tion, ATP levels with elevated concentrations of ADP, leading to HF and death $[90,200,201]$. These deficiencies could be reversed by administration of either the $\beta$-AR agonist, isoproterenol, or the $\alpha_{1}$-AR agonist, phenylephrine [201]. The addition of pyruvate also led to a recovery of the ATP loss, suggesting that the loss of cardiac glycolysis prevented sufficient substrate for aerobic respiration [90]. Targeted disruption of the pathway that leads to only Epi biosynthesis does not affect heart development nor develops HF [202,203]. These results suggest that NE by stimulating both $\alpha_{1}$ - and $\beta$-ARs are essential for heart development and metabolism by regulating the embryonic shift from anaerobic glycolysis to aerobic metabolism and oxidative phosphorylation in the heart.

In general, catecholamines have also been shown to increase glucose uptake, glycolysis, and glucose and fatty acid oxidation in the adult heart [204-207] driving fatty acid oxidation at much less levels ( $10 \%$ increase) versus a much larger proportion $(410 \%$ increase) in glucose oxidation [208]. Catecholamines also increase lipolysis in fat cells, reduce insulin release and insulin sensitivity which can lead to metabolic effects on the heart [209-211].

\section{1. $\alpha_{1}-A R s$}

Early studies on the role of $\alpha_{1}$-ARs in metabolism have shown increased gluconeogenesis and ketogenesis in both the liver [212-216] and in the kidneys [217,218]. The mechanism is through calcium release and the phosphorylation of glycogen phosphorylase $[219,220]$. Both the liver and kidneys are gluconeogenic organs and both can increase systemic glucose production. Glucose and sodium metabolism are linked as the kidneys reabsorb glucose through sodium-glucose cotransporters (SGLT) 1 and 2. SGLT inhibitors and inhibition of glucose reabsorption can improve hemodynamics to reduce adverse outcomes in HF [221,222], postulated to occur through increasing fuel efficiency, utilization, and oxygen delivery [221] SGLT inhibitors also induce a fast-like metabolic state that enhances gluconeogenesis and ketogenesis [223], unlike traditional antihyperglycemic agents such as insulin or metformin which suppresses both gluconeogenesis and ketogenesis $[224,225]$. Ketone bodies are highly efficient source of energy and improve heart work efficiency [226] and more so during HF in the diabetic where glucose metabolism is impaired due to insulin resistance [227]. Ketones are also anti-inflammatory [228-230] and antioxidant [231], all protective mechanisms in HF. We speculate that $\alpha_{1}$-AR agonists may confer part of their cardioprotective benefits and limit the progression of HF, particularly in the diabetic heart, by metabolically increasing glucose and ketone body availability through enhanced glucogenesis and ketogenesis.

Glucose uptake is increased in the heart during ischemia via translocation of the glucose transporters GLUT 1 and GLUT 4 [232]. Both GLUT isoforms 1 and 4 are decreased in human HF [111]. $\alpha_{1}$-AR stimulation can increase glucose substrate availability by increasing its uptake into the heart or in myocytes [232-236] and also in a wide variety of cell lines and cell types such as L6 and C2C12 muscle cells [237-239], and adipocytes [240-244]. The mechanism of glucose uptake in the heart is through $\alpha_{1}$-AR stimulation of PKC activation which increase translocation of GLUT 1 or 4 to the membrane resulting in GLUT activation $[234,245]$ (Figure 1). $\alpha_{1}$-AR mediated ${ }^{3} \mathrm{H}$-deoxyglucose uptake was blocked by an inhibitor of GLUT 1 or 4 translocation and by the PKC inhibitor rottlerin or siRNA against PKC $\delta$ [246]. $\alpha_{1 \mathrm{~A}^{-}}$and $\alpha_{1 \mathrm{~B}}-\mathrm{AR}$ KO mice $[23,246]$ or transgenic mice designed with large fragments of their endogenous promoters to drive systemic overexpression of the $\alpha_{1 A^{-}}$or $\alpha_{1 B}-A R$ subtypes with constitutively active mutations (CAMs) [247-249] were used to discern effects of the specific $\alpha_{1}-\mathrm{AR}$ subtypes on metabolism. The $\alpha_{1 \mathrm{~A}}-\mathrm{AR}$ and not the $\alpha_{1 B}$-AR subtype appears selective for glucose uptake in the heart as only transgenic CAM $\alpha_{1 \mathrm{~A}}-$ but not $\mathrm{CAM} \alpha_{1 \mathrm{~B}}$-ARs increased glucose uptake in the heart and plasma membrane translocation of both GLUT1 and GLUT4. In congruence, knockout (KO) of the $\alpha_{1 \mathrm{~A}}$-AR but not $\alpha_{1 \mathrm{~B}}-\mathrm{AR}$ mice decreased glucose uptake and GLUT translocation $[234,250]$. The $\alpha_{1 \mathrm{~A}}$-selective agonist, A61603 also increased glucose uptake into primary myocytes [235]. $\alpha_{1 \mathrm{~A}}-\mathrm{AR}$ stimulation also increased glucose uptake during glucose-starved conditions of ischemia and protected against annexin $\mathrm{V}^{+}$apoptosis and increased levels of lactate de- 
hydrogenase [232,250]. These results suggest that $\alpha_{1 \mathrm{~A}}$-AR-mediated regulation of glucose uptake in the heart would provide the needed increased metabolic requirements in HF but also provide cardioprotective benefits against apoptosis and cell death.

Without a concomitant increase in glucose oxidation, an increase in glucose substrate is not energy efficient and of limited benefit in HF. Recently, studies have indicated that $\alpha_{1 \mathrm{~A}}$-AR agonists would also not only increase glucose uptake and availability but also increase its oxidation in the heart. Using radioactive tracers of ${ }^{14} \mathrm{C}$-glucose or ${ }^{14} \mathrm{C}$-palmitate to measure oxidation rates in primary cardiac myocytes, $\alpha_{1}$-AR stimulation with phenylephrine increased glucose oxidation which was blocked by an inhibitor to AMP-activated protein kinase (AMPK) [236], under both normal and diseased (i.e., ischemic) conditions. Therefore, $\alpha_{1 \mathrm{~A}}-\mathrm{AR}$ agonist treatment may promote energy efficiency and increase the needed ATP in the failing heart by increasing both glucose substrate availability and its subsequent oxidation.

AMPK is a key regulator of energy metabolism and plays a cardioprotective role. AMPK activation is protective in the heart against ischemic damage [251-253], cardiac hypertrophy [254] and decreases inflammation and fibrosis [255-258]. AMPK is an energy sensor that measures the ratio of AMP to ATP to regulate ATP-generating pathways but also prevent oxidative stress by improving and $\mathrm{NAD}^{+}$homeostasis [259-261]. AMPK regulates glucose metabolism in myocytes by increasing the translocation of GLUT and activating PKC to increase glycolysis during ischemia [262,263] (Figure 1). $\alpha_{1}$-ARs have been readily shown to activate AMPK in the heart $[253,255,264,265]$. $\alpha_{1}$-AR mediated ischemic protection is mediated through PKC and AMPK [253] and induces GLUT4 upregulation [251,266] and is shared with the $\alpha_{1}$-AR signals that mediates glucose oxidation [236,250] (Figure 1). Therefore, $\alpha_{1}$-AR metabolic effects and protective signals in the heart may both be regulated through AMPK.

While the systemically expressing CAM $\alpha_{1}$-AR mice can improve glucose tolerance and the $\alpha_{1 \mathrm{~A}}$-AR subtype specifically regulated glucose uptake in the heart, whole body indirect calorimetry found that both CAM $\alpha_{1 \mathrm{~A}}$ and CAM $\alpha_{1 \mathrm{~B}}$ mice had increased whole body fatty acid oxidation by increasing its preference to burn fatty acids as an energy substrate even though they were fed a normal chow diet [234]. In congruence, $\alpha_{1}-\mathrm{AR} K O$ mice from both subtypes increased whole body glucose oxidation by increasing the preference to burn carbohydrates [234]. The ability to regulate both glucose and fatty acid oxidation suggests that $\alpha_{1}$-ARs may regulate and switch energy fuel preference through coupling to AMPK. $\alpha_{1}$-ARs can regulate AMPK activity not only in the heart $[253,257,264,265]$ but in a wide variety of cell types such as in liver [267], adipose [268], skeletal muscle [239,269] and CHO transfected cells [270]. It is likely that $\alpha_{1}$-AR CAM mice increased whole body fatty acid oxidation through stimulating fatty acid oxidation in the skeletal muscle as that muscle utilizes $40-50 \%$ of a body's whole energy metabolism. The CAM $\alpha_{1}$-AR mice also had increased levels of leptin in the plasma while $\alpha_{1}$-AR KO mice had decreased leptin levels [234]. Leptin can increase the oxidation of glucose in skeletal muscle in the absence of insulin [271,272] or can stimulate fatty acid oxidation in skeletal muscle by activating AMPK and inhibiting acetyl coenzyme A carboxylase, which inhibits carnitine palmitoyltransferase 1 through decreased levels of malonyl-CoA [269] (Figures 1 and 2). During HF where there is metabolic inflexibility on the use of fuel substrates [273,274], the ability of $\alpha_{1}$-AR activation to regulate and shift energy pathways as needed may lead to better outcomes.

$\alpha_{1}$-AR stimulation can also activate PPARs, in addition to AMPK, to regulate oxidative phosphorylation, glucose homeostasis, ROS, and hypertrophic responses in myocytes [274-278]. PPARs are crucial to maintain normal cardiac function, its energy requirements, and regulates many key metabolic oxidative processes and mitochondrial biogenesis and function [279-281]. PPARs are also cardioprotective, particularly PPAR [282]. Cardiac-targeted $\mathrm{KO}$ of PPAR decreases basal fatty acid oxidation leading to cardiac dysfunction, lipid accumulation and HF [283]. Cardiac-targeted overexpression of PPAR $\beta$ /increased glucose utilization [281]. Both PPAR $\alpha$ and PPAR activation as well as $\alpha_{1}$-AR agonists increased 
AMPK phosphorylation and glucose uptake in the heart [274]. $\alpha_{1}$-AR stimulation in the heart reverses ROS and mitochondrial dysfunction when co-treated with PPAR $\alpha$ agonists [275,276] or PPAR co-activators [277] (Figure 1). As PPAR activators can rescue HF through metabolic alterations and are being pursued as therapeutics [284,285], PPAR activators have different and sometimes detrimental outcomes in noncardiac tissues and may induce tumorigenesis [286-289]. Therefore, $\alpha_{1}$-AR agonists may offer a better treatment option in HF by its ability to target PPAR signals in the heart.

$\alpha_{1}$-ARs, and the $\alpha_{1 \mathrm{~A}}$-AR in particular, also have general effects on glucose homeostasis that may be of benefit to treat HF. $\alpha_{1 \mathrm{~A}}$ and $\alpha_{1 \mathrm{~B}}$-AR KO mice $[23,246]$ or the CAM transgenic mice [247-249] were assessed for whole body metabolic changes. Both CAM $\alpha_{1 \mathrm{~A}}$ and CAM $\alpha_{1 \mathrm{~B}}-\mathrm{AR}$ transgenic mice had an increased tolerance for glucose. However, CAM $\alpha_{1 \mathrm{~A}}-\mathrm{AR}$ mice were more robust in glucose control and only the CAM $\alpha_{1 \mathrm{~A}}-\mathrm{AR}$ mice had statistically lowered fasting glucose levels. The $\alpha_{1 \mathrm{~A}}$-AR KO mice had elevated blood glucose after fasting [234]. The CAM $\alpha_{1 \mathrm{~A}}-\mathrm{AR}$ mice also specifically reduced fasting plasma triglycerides levels while only the $\alpha_{1 \mathrm{~A}}$-AR KO mice had elevated levels [250]. $\alpha_{1}$-AR agonists have also been shown to reduce serum triglycerides [290]. In a metabolomic analysis, the $\alpha_{1 A^{-}}$ AR selective agonist, A61603, produced a reduction in polyunsaturated fatty acids in the heart [291]. While there is a report that the $\alpha_{1 \mathrm{~B}}-\mathrm{AR} \mathrm{KO}$ mice had impaired glucose homeostasis, insulin resistance and reduced glycogen synthesis [292], the phenotype only appeared when the mice were fed a high fat diet. These results suggest that an $\alpha_{1 \mathrm{~A}}-\mathrm{AR}$ agonist may provide improved blood lipid and carbohydrate profiles if used as a potential therapeutic to treat HF.

Additional beneficial effects on glucose utilization were shown when either $\alpha_{1}$ - and $\beta$-AR stimulation increased PPP activity in the heart through increasing the mRNA and protein synthesis of G6PD [293-296] (Figure 1). In corroboration, carvedilol which antagonizes both the $\beta$ - and $\alpha_{1}$-ARs [297], blocks PPP activity [298]. Catecholamine deletion due to dopamine $\beta$-hydroxylase $\mathrm{KO}$ also produced decreased G6PD activity [91]. Therefore, an additional benefit of $\alpha_{1 \mathrm{~A}}$-AR agonism to treat $\mathrm{HF}$ would be its generation of NADPH through the PPP to protect the heart against ROS damage.

\section{2. $\alpha_{1 A}-A R$ Therapeutics}

The above review suggests that the $\alpha_{1 \mathrm{~A}}$-AR subtype may be a therapeutic target for its ability to metabolically protect the heart during failure. However, $\alpha_{1 \mathrm{~A}}$-AR agonists have not been extensively developed in the past because of its ability to also increase blood pressure [299-303]. However, to circumvent non-desirable blood pressure effects, $\alpha_{1 A}-A R$ agonists are being currently developed that either bias or allosterically prevent signals (i.e., IP3 or calcium release) away from those that induce the blood pressure response.

$\alpha_{2}$-AR and not $\alpha_{1}$-AR agonists commonly contain the imidazoline pharmacophore and, in general, have better selectivity for $\alpha_{2}$-ARs. $\alpha_{2}$-AR agonists reduce blood pressure by decreasing NE release at the $\alpha_{2 \mathrm{~A}}$-AR autoreceptor on sympathetic nerve endings [304] and also are weak antagonists at the $\alpha_{1}-\mathrm{AR}$ [305]. However, depending upon the substituents off the imidazoline ring structure, some imidazolines can be designed to become high affinity $\alpha_{1}$-AR selective agonists [306-308]. Imidazolines also have about 50-fold higher selectivity for the $\alpha_{1 \mathrm{~A}}$-AR subtype compared to the $\alpha_{1 \mathrm{~B}}-$ or $\alpha_{1 \mathrm{D}}$-AR subtypes [309,310]. There are several imidazolines (i.e., cirazoline, A61603, dabuzalgron) that are $\alpha_{1 \mathrm{~A}}$-AR selective and shown to reduce stress urinary incontinence without a strong response on blood pressure by biasing the signaling towards cAMP and not the IP3 $/ \mathrm{Ca}^{+2}$ response [311-314] and demonstrated to have improve function or protect during $\operatorname{HF}[38,39,80,81]$. The ability of $\alpha_{1 \mathrm{~A}}$-AR structured imidazolines to separate cardioprotection from the blood pressure effect would depend upon the therapeutic index or the dose of the drug that can separate therapeutic efficacy from toxic side effects. Dabuzalgron (aka Ro 115,1240), for example, was taken to Phase 11 clinical trials showing improvement in stress urinary incontinence with little or no cardiovascular effect [311] but did not meet the efficacy hurdle as stated in the clinical trial [315]. 
Another area of drug development for $\alpha_{1 \mathrm{~A}}$-AR agonists are positive allosteric modulators (PAMs) that increase a receptor's function but does not bind to the orthosteric (i.e., endogenous) site that agonists bind, such as NE [316]. Allosteric modulators result in greater selectivity by binding to non-conserved regions of the receptor and several advantages over orthosteric agonists, such as usually having conformational bias that can alter the receptor's signaling pathways [316]. There are now many GPCR allosteric modulators in clinical trials [317,318]. The first PAM at the $\alpha_{1}$-ARs with selectivity for the $\alpha_{1 \mathrm{~A}}$-AR subtype has been developed [319] that can improve the cognitive functions in an Alzheimer's Disease mouse model without increased blood pressure.

\section{3. $\beta_{2}$-ARs}

Similar to $\alpha_{1}$-ARs, $\beta_{1}$-AR but not $\beta_{2}$-AR stimulation increases glycogenolysis by the phosphorylation and activation of glycogen phosphorylase [320]. Under increased workload and higher energy requirements in the heart during failure, $\beta_{1}$-AR agonists can increase anaerobic metabolism when needed [321] and may do so through increased glycogenolysis and subsequent glucose metabolism [208,322,323]. While $\beta$-AR stimulation of cAMP increases glucose uptake via GLUT translocation in skeletal cells [324,325], but it has not been shown in myocytes directly. $\beta$-AR agonism can reduced the levels of metabolites found in the Krebs cycle, glycogen metabolism, and glycolysis [326], suggesting that $\beta$-AR stimulation increases the oxidation of glucose in the heart and may benefit HF. $\beta_{1}$-ARs appear to increase oxidative metabolism at a greater rate than the $\beta_{2}$-AR [327] and may explain why downregulation of the $\beta_{1}$-AR in HF is detrimental. While inotropic interventions for HF might improve short-term hemodynamics, $\beta$-AR agonists have longterm effects that have failed to improve outcomes and can even worsen as excessive release of catecholamines induces apoptosis, increased heart rate, and arrhythmias [328,329].

$\beta_{3}$-ARs have been mostly studied in adipose cells to increase cAMP levels, activation of lipase, and thermogenesis $[330,331]$. Most studies suggest that the $\beta_{3}$-AR produces a negative inotropy in opposition to positive inotropy regulated by the $\beta_{1}$ - or $\beta_{2}$-AR $[14,16]$, is cardioprotective [59], and upregulated during human HF [60,332]. As the $\beta_{3}$-AR does not desensitize and may even increase during HF [65,333-335], a $\beta_{3}$-AR agonist may also provide metabolic benefit. However, the role of the $\beta_{3}$-AR in HF is controversial. One study suggests that cardiac function can be recovered in HF by blocking the $\beta_{3^{-}}$ AR which improves the energy efficiency in myocardial tissues by suppressing iNOS expression [336]. A $\beta_{3}$-AR KO mouse model is cardioprotective [337]. In contrast, there are far more abundant studies that indicate that $\beta_{3}$-AR stimulation or cardiac-overexpression is cardioprotective in many models of ischemia, pressure overload and hypertrophy through inducing nitric oxide (NO) $[59,338-344]$. Therefore, $\beta_{3}$-AR agonism may still be a viable metabolic therapeutic candidate for HF.

The $\beta_{3}$-AR agonist, mirabegron, can improve glucose homeostasis in insulin-resistant obese humans although this occurs through its function on brown adipose tissue [345]. Mirabegron reduced adipose tissue dysfunction and resulted in improved whole-body glucose tolerance, increased lipolysis and expression of PPAR and enhanced oxidative capacity $[345,346]$. Mirabegron and other $\beta_{3}$-AR agonists improved glucose tolerance, utilization [347] and insulin sensitivity in lean mice [348] or mice fed a high fat diet [349,350]. $\beta_{3}$-AR agonism is anti-atherosclerotic in apoE KO mice with decreased plasma triglycerides, low density lipoproteins, cholesterol, and increased insulin sensitivity and PPAR $\alpha$ and expression in the liver [351,352]. These results suggest that $\beta_{3}$-AR agonists can regulate whole body lipid and glucose metabolism. While a clinical trial of mirabegron failed to improve left ventricular ejection fraction in HF [353], there was significant improvement in a subset of patents with ejection fractions under $40 \%$. This suggest that mirabegron may be therapeutic in HF patients with reduced ejection fraction. There is an ongoing large-scale clinical trial to confirm this effect of mirabegron therapy on improving function in patients with progressive left ventricular remodeling [354]. 


\section{4. $\beta_{1}$-AR Therapeutics}

With the subsequent downregulation of $\beta_{1}$-ARs in HF and worse outcomes with long-term stimulation, the metabolic effects of $\beta$-blockers to treat $\mathrm{HF}$ are preferred. $\beta$-AR blockers are a standard therapy in the treatment of HF by reducing sympathetic overdrive resulting in increased ejection fraction and survival [56]. However, $\beta$-AR blockers may also improve outcomes through its effects on energy substrate utilization and metabolic efficiency by using oxygen-sparing mechanisms $[355,356]$. As fatty acid oxidation in the heart utilizes more oxygen per unit of ATP generation, it is less efficient as compared to glucose oxidation $[171,172,357]$. Early studies studying the effects of $\beta$-AR blockage on general metabolism suggests that $\beta$-AR antagonists induce hypoglycemia and decrease the breakdown of glycogen [358-361]. Some clinicians are reluctant to prescribe $\beta$-AR blockers for $\mathrm{HF}$ because of negative inotropic and these general metabolic effects, including loss of glycemic control and insulin resistance [358-361]. However, the major effect of $\beta$-AR blockage in the heart is the suppression of lipolysis, decreased fatty acid uptake, and a reduction in myocardial fatty acid oxidation which may result in a compensatory increase in glucose oxidation and its resulting metabolic benefit in treating HF [362-368] (Figure 2). Furthermore, studies have shown that not all $\beta$-AR blockers are equal in their metabolic effects. Carvedilol, which is vasodilating (through $\alpha_{1 \mathrm{~B}}$-AR blockage) in addition to its $\beta$-AR blockage, have metabolic effects that contribute to better outcomes in HF, compared with pure $\beta$-AR blockers [369-375].

Studies have also suggested that $\beta$-AR blockers may also increase cardiac mitochondrial respiration [376-379] and have anti-oxidative effects [380], along with regulating mitochondrial calcium levels and ADP uptake [381,382]. Mitochondrial abnormalities are associated with HF $[383,384]$. PPARs regulates many key metabolic oxidative processes and mitochondrial biogenesis and function [279-281]. As mentioned for $\alpha_{1}$-AR agonists coupling to PPARs, PPAR activators increase mitochondrial oxidative capacity in the heart [280] and is cardioprotective [282]. Isoproterenol-induced HF can be rescued though PPAR $\alpha$ activation [284,287], suggesting that $\beta_{1}$-AR stimulation decreases PPAR activation. Similarly, $\beta_{1}$-AR autoantibodies induce a positive inotropy in the heart [385] but also induce HF [386,387], apoptosis [388] and inhibit the PPAR pathway [389,390]. However, the metabolic protective effects of a $\beta_{2}$-AR agonist, higenamine, against mitochondrial and respiratory dysfunction is mediated though increased PPAR $\alpha$ signals [391] (Figure 2). These results suggest that $\beta_{1}$-AR selective blockers may be better at increasing mitochondrial function during HF than non-selective $\beta$-blockers.

Besides generating ATP, mitochondria are the main produces of ROS, generated during oxidative phosphorylation [392,393]. Mitochondrial-targeted antioxidants are gaining acceptance as an emerging therapy for HF [394]. Results from two small clinical studies suggest $\beta$-AR blockers can decrease fatty acid uptake and oxidation $[366,368]$ (Figure 2), while increasing LV function in the absence of increased oxygen utilization which would limit ROS formation [394,395]. In patients with HF, long-term usage of $\beta$-AR blockers reduced the metabolic demand of oxygen on the heart and lowered oxidative stress and ROS damage [102,396-402]. Therefore, $\beta$-AR blockers would also limit ROS damage, an additional benefit as a metabolic therapeutic in HF.

The best described $\beta$-AR blocker and its effects on cardiac metabolism is carvedilol. Carvedilol is a $\beta$-AR antagonist and an $\alpha_{1}$-AR antagonist [403]. The $\alpha_{1}$-AR blocking ability of carvedilol has been downplayed in its cardiac protective potential as non-selective $\alpha_{1}$-AR blockers can increase the morbidity of heart failure [404]. However, carvedilol has a little higher selectivity for $\beta_{2}$ - versus $\beta_{1}$-ARs $[405,406]$ and has 10 -fold higher affinity for the $\alpha_{1 \mathrm{~B}}$-ARs versus $\alpha_{1 \mathrm{~A}}$-ARs and binds with higher affinity at $\alpha_{1}$-ARs than at $\beta_{1}$-ARs [407]. A possible explanation for carvedilol's better outcomes in HF when compared to other $\beta$-AR blockers is its ability to selectivity block the $\alpha_{1 \mathrm{~B}}-\mathrm{AR}$. The $\alpha_{1 \mathrm{~B}}-\mathrm{AR}$, unlike the $\alpha_{1 \mathrm{~A}^{-}}$ AR [1], mediates maladaptive effects on the heart [35,84,85,407] and does not mediate glucose metabolism in the heart $[234,235,250]$, but still would produce vasodilation that has positive effects on heart function by decreasing heart rate and vascular resistance. 
Therefore, selective blockage of the $\alpha_{1 \mathrm{~B}}$-AR by carvedilol would decrease its maladaptive effects in the heart and not disrupt the metabolic and other cardioprotective benefits of the $\alpha_{1 \mathrm{~A}}$-AR.

In clinical studies, carvedilol has better cardioprotective metabolic properties than other $\beta$-blockers and may be a preferred treatment for HF. Carvedilol is better than metoprolol in its antioxidative properties [408-411] and has more favorable effects on glucose metabolism [412] and calcium load [413]. Carvedilol shifts the heart energy substrate usage from fatty acids to glucose oxidation $[315,368]$ by decreasing free fatty acids, inhibiting fatty acid oxidation, resulting in increased glycolysis, oxidation and energy efficiency [364,395,414,415] (Figure 2). Mechanisms of cardioprotective effects of carvedilol are linked to oxidative metabolism and decreases in oxidative stress [102,327,363,414-418], which reduces the impairment of mitochondrial metabolism during HF [419]. Carvedilol can also improve insulin sensitivity and plasma lipid profile [419-421]. The net effect of these metabolic changes are favorable effects on glucose metabolism [412,421], by improving myocardial energy efficiency through increased carbohydrate utilization [395,422,423], similar to $\alpha_{1 \mathrm{~A}}$-AR agonism.

Carvedilol's mechanism to shift metabolism to glucose utilization is also an AMPKmediated mechanism, similar to $\alpha_{1}$-AR stimulation [424]. AMPK can increase fatty acid oxidation by increasing fatty acid uptake, increasing the expression of the fatty acid transporters, and by decreasing levels of malonyl-CoA, a potent inhibitor of carnitine palmitoyltransferase $1[425,426]$ (Figure 2). $\beta$-ARs have been shown to regulate AMPK in the heart [427] and the decrease in responsiveness in $\beta$-ARs during heart failure and its associated pathological remodeling has been linked to $\beta$-AR's associated loss of AMPK signals [428-430]. As $\beta_{1}$-ARs are downregulated in HF, $\beta$-AR blockers may reactivate AMPK pathways to shift metabolism to glucose utilization. The $\beta_{3}$-AR is also postulated to mediate its exercise-mediated cardioprotection through activation of AMPK signals [431].

\section{Conclusions}

While inotropic interventions for HF might improve contractile function for the shortterm, chronic treatments have failed to improve outcomes. During the progression of HF there is a tremendous amount of metabolic inflexibility [273] caused by the progressive dysfunction of the metabolic pathways that generate ATP which starve the heart. Our current understanding of the failing heart suggests that optimizing energy substrate metabolism by inhibiting fatty acid oxidation while increasing glucose substrate availability in conjunction with its oxidation may provide a means to increase the efficiency of ATP production that is needed to maintain the high energy demands of cardiac function. Since severe HF also has diminished mitochondrial function, metabolic therapies that are multi-faceted and regulate key metabolic sensors may provide greatest benefit during all of the stages of HF. $\alpha_{1}$ - and $\beta$-ARs regulate cardiac metabolism in opposition with $\alpha_{1 \mathrm{~A}}$-AR agonism and $\beta$-AR blockage converging on increasing glucose availability and oxidation, suggesting that a dual action drug might provide the greatest therapeutic benefit. The ability of $\beta$-AR antagonists and $\alpha_{1 \mathrm{~A}}-\mathrm{AR}$ agonists to regulate, optimize, and shift energy pathways as needed by the heart during failure are also predicted to lead to better outcomes.

Funding: This work was supported by a grant from The Edward N. \& Della L. Thome Memorial Foundation Award Programs in Alzheimer's Disease Drug Discovery Research and an RO1 from the National Institute of Aging (AG066627).

Conflicts of Interest: The authors declare no conflict of interest.

\section{References}

1. Perez, D.M.; Doze, V.A. Cardiac and neuroprotection regulated by $\alpha_{1}$-adrenergic receptor subtypes. J. Recept. Signal. Transduct. Res. 2011, 31, 98-110. [CrossRef]

2. Stadel, J.M.; Namb, I.P.; Shorr, R.G.; Sawyer, D.F.; Caron, M.G.; Lefkowitz, R.J. Catecholamine-induced desensitization of turkey erythrocyte adenylate cyclase is associated with phosphorylation of the $\beta$-adrenergic receptor. Proc. Natl. Acad. Sci. USA 1983, 80, 3173-3177. [CrossRef] 
3. Hausdorff, W.P.; Caron, M.G.; Lefkowitz, R.J. Turning off the signal: Desensitization of b-adrenergic receptor function. FASEB J. 1990, 4, 2881-2889. [CrossRef] [PubMed]

4. $\quad$ Bristow, M.R.; Ginsburg, R.; Umans, V.; Fowler, M.; Minobe, W.; Rasmussen, R.; Zera, P.; Menlove, R.; Shah, P.; Jamieson, S.; et al. $\beta_{1}$ - and $\beta_{2}$-adrenergic-receptor subpopulations in nonfailing and failing human ventricular myocardium: Coupling of both receptor subtypes to muscle contraction and selective $\beta_{1}$-receptor down-regulation in heart failure. Circ. Res. 1986, 59, 297-309. [CrossRef]

5. Brodde, O.E. $\beta_{1}$ - and $\beta_{2}$-adrenoceptors in the human heart: Properties, function, and alterations in chronic heart failure. Pharmacol. Rev. 1991, 43, 203-242. [PubMed]

6. Sulakhe, P.V.; Vo, X.T. Regulation of phospholamban and troponin-I phosphorylation in the intact rat cardiomyocytes by adrenergic and cholinergic stimuli: Roles of cyclic nucleotides, calcium, protein kinases and phosphatases and depolarization. Mol. Cell Biochem. 1995, 149-150, 103-126. [CrossRef] [PubMed]

7. Xiang, Y.; Kobilka, B.K. Myocyte adrenoceptor signaling pathways. Science 2003, 300, 1530-1532. [CrossRef]

8. Xiao, R.P.; Zhu, W.; Zheng, M.; Cao, C.; Zhang, Y.; Lakatta, E.G.; Han, Q. Subtype-specific $\alpha_{1}$ - and $\beta$-adrenoceptor signaling in the heart. Trends Pharmacol. Sci. 2006, 27, 330-337. [CrossRef]

9. Bers, D.M. Calcium cycling and signaling in cardiac myocytes. Annu. Rev. Physiol. 2008, 70, 23-49. [CrossRef]

10. Communal, C.; Singh, K.; Sawyer, D.B.; Colucci, W.S. Opposing effects of $\beta_{1}$ - and $\beta_{2}$-adrenergic receptors on cardiac myocyte apoptosis: Role of a pertussis toxin-sensitive G protein. Circulation 1999, 100, 2210-2212. [CrossRef] [PubMed]

11. Chesley, A.; Lundberg, M.S.; Asai, T.; Xiao, R.P.; Ohtani, S.; Lakatta, E.G.; Crow, M.T. The $\beta_{2}$-adrenergic receptor delivers an antiapoptotic signal to cardiac myocytes through $\mathrm{G}(\mathrm{i})$-dependent coupling to phosphatidylinositol 3'-kinase. Circ. Res. 2000, 87, 1172-1179. [CrossRef]

12. Zhu, W.Z.; Zheng, M.; Koch, W.J.; Lefkowitz, R.J.; Kobilka, B.K.; Xiao, R.P. Dual modulation of cell survival and cell death by $\beta_{2}$-adrenergic signaling in adult mouse cardiac myocytes. Proc. Natl. Acad. Sci. USA 2001, 98, 1607-1612. [CrossRef] [PubMed]

13. Gauthier, C.; Tavernier, G.; Charpentier, F.; Langin, D.; Le Marec, H. Functional $\beta_{3}$-adrenoceptor in the human heart. J. Clin. Investig. 1996, 98, 556-562. [CrossRef]

14. Gauthier, C.; Leblais, V.; Kobzik, L.; Trochu, J.N.; Khandoudi, N.; Bril, A.; Balligand, J.L.; Le Marec, H. The negative inotropic effect of $\beta_{3}$-adrenoceptor stimulation is mediated by activation of a nitric oxide synthase pathway in human ventricle. J. Clin. Investig. 1998, 102, 1377-1384. [CrossRef] [PubMed]

15. Varghese, P.; Harrison, R.W.; Lofthouse, R.A.; Georgakopoulos, D.; Berkowitz, D.E.; Hare, J.M. $\beta_{3}$-adrenoceptor deficiency blocks nitric oxide-dependent inhibition of myocardial contractility. J. Clin. Investig. 2000, 106, 697-703. [CrossRef]

16. Tavernier, G.; Toumaniantz, G.; Erfanian, M.; Heymann, M.F.; Laurent, K.; Langin, D.; Gauthier, C. $\beta_{3}$-Adrenergic stimulation produces a decrease of cardiac contractility ex vivo in mice overexpressing the human $\beta_{3}$-adrenergic receptor. Cardiovasc. Res. 2003, 2, 288-296. [CrossRef]

17. Steinfath, M.; Chen, Y.Y.; Lavicky, J.; Magnussen, O.; Nose, M.; Rosswag, S.; Schmitz, W.; Scholz, H. Cardiac $\alpha_{1}$-adrenoceptor densities in different mammalian species. Br. J. Pharmacol. 1992, 107, 185-188. [CrossRef]

18. Michel, M.C.; Hanft, G.; Gross, G. Radioligand binding studies of $\alpha_{1}$-adrenoceptor subtypes in rat heart. Br. J. Pharmacol. 1994, 111, 533-538. [CrossRef]

19. Scofield, M.A.; Liu, F.; Abel, P.W.; Jeffries, W.B. Quantification of steady state expression of mRNA for $\alpha_{1}$-adrenergic receptor subtypes using reverse transcription and a competitive polymerase chain reaction. J. Pharmacol. Exp. Ther. 1995, 275, 1035-1042.

20. Turnbull, L.; McCloskey, D.T.; O'Connell, T.D.; Simpson, P.C.; Baker, A.J. $\alpha_{1}$-adrenergic receptor responses in $\alpha_{1 \mathrm{AB}}$-AR knockout mouse hearts suggest the presence of $\alpha_{1 \mathrm{D}}$-AR. Am. J. Physiol. Heart Circ. Physiol. 2003, 284, H1104-H1109. [CrossRef]

21. Jensen, B.C.; Swigart, P.M.; De Marco, T.; Hoopes, C.; Simpson, P.C. $\alpha_{1}$-Adrenergic receptor subtypes in nonfailing and failing human myocardium. Circ. Heart Fail. 2009, 2, 654-663. [CrossRef]

22. Methven, L.; Simpson, P.C.; McGrath, J.C. $\alpha_{1 \mathrm{~A} / \mathrm{B}}-\mathrm{knockout}$ mice explain the native $\alpha_{1 \mathrm{D}}$-adrenoceptor's role in vasoconstriction and show that its location is independent of the other $\alpha_{1}$-subtypes. Br. J. Pharmacol. 2009, 158, 1663-1675. [CrossRef]

23. Rokosh, D.G.; Simpson, P.C. Knockout of the $\alpha_{1 \mathrm{~A} / \mathrm{C}}$-adrenergic receptor subtype: The $\alpha_{1 \mathrm{~A} / \mathrm{C}}$ is expressed in resistance arteries and is required to maintain arterial blood pressure. Proc. Natl. Acad. Sci. USA 2002, 99, 9474-9479. [CrossRef] [PubMed]

24. Piascik, M.T.; Perez, D.M. $\alpha_{1}$-adrenergic receptors: New insights and directions. J. Pharmacol. Exp. Ther. 2001, 298, 403-410. [PubMed]

25. Otani, H.; Otani, H.; Das, D.K. $\alpha_{1}$-adrenoceptor-mediated phosphoinositide breakdown and inotropic response in rat left ventricular papillary muscles. Circ. Res. 1988, 62, 8-17. [CrossRef]

26. Pucéat, M.; Terzic, A.; Clément, O.; Scamps, F.; Vogel, S.M.; Vassort, G. Cardiac $\alpha_{1}$-adrenoceptors mediate positive inotropy via myofibrillar sensitization. Trends Pharmacol. Sci. 1992, 13, 263-265. [CrossRef]

27. Endoh, M. Cardiac $\alpha_{1}$-Adrenoceptors and Inotropy: Myofilament $\mathrm{Ca}^{2+}$ Sensitivity, Intracellular $\mathrm{Ca}^{2+} \mathrm{Mobilization,} \mathrm{Signaling}^{2}$ Pathway, and Pathophysiological Relevance. Circ. Res. 2016, 119, 587-590. [CrossRef] [PubMed]

28. Venema, R.C.; Raynor, R.L.; Noland, T.A., Jr.; Kuo, J.F. Role of protein kinase C in the phosphorylation of cardiac myosin light chain. Biochem. J. 1993, 294, 401-406. [CrossRef]

29. Snabaitis, A.K.; Yokoyama, H.; Avkiran, M. Roles of mitogen-activated protein kinases and protein kinase C in $\alpha_{1 \mathrm{~A}}$-adrenoceptormediated stimulation of the sarcolemmal Na+-H+ exchanger. Circ. Res. 2000, 86, 214-220. [CrossRef] 
30. Yu, Z.Y.; Tan, J.C.; McMahon, A.C.; Iismaa, S.E.; Xiao, X.H.; Kesteven, S.H.; Reichelt, M.E.; Mohl, M.C.; Smith, N.J.; Fatkin, D.; et al. RhoA/ROCK signaling and pleiotropic $\alpha_{1 \mathrm{~A}}$-adrenergic receptor regulation of cardiac contractility. PLoS ONE 2014, 9 , e99024. [CrossRef]

31. Taniguchi, M.; Okamoto, R.; Ito, M.; Goto, I.; Fujita, S.; Konishi, K.; Mizutani, H.; Dohi, K.; Hartshorne, D.J.; Itoh, T. New Isoform of Cardiac Myosin Light Chain Kinase and the Role of Cardiac Myosin Phosphorylation in $\alpha_{1}$-Adrenoceptor Mediated Inotropic Response. PLoS ONE 2015, 10, e0141130. [CrossRef]

32. Endoh, M.; Hiramoto, T.; Ishihata, A.; Takanashi, M.; Inui, J. Myocardial $\alpha_{1}$-adrenoceptors mediate positive inotropic effect and changes in phosphatidylinositol metabolism. Species differences in receptor distribution and the intracellular coupling process in mammalian ventricular myocardium. Circ. Res. 1991, 68, 1179-1190. [CrossRef] [PubMed]

33. Lin, F.; Owens, W.A.; Chen, S.; Stevens, M.E.; Kesteven, S.; Arthur, J.F.; Woodcock, E.A.; Feneley, M.P.; Graham, R.M. Targeted $\alpha_{1 \mathrm{~A}}$-adrenergic receptor overexpression induces enhanced cardiac contractility but not hypertrophy. Circ. Res. 2001, 89, 343-350. [CrossRef]

34. Janssen, P.M.L.; Canan, B.D.; Kilic, A.; Whitson, B.A.; Baker, A.J. Human Myocardium Has a Robust $\alpha_{1 A}-$ Subtype Adrenergic Receptor Inotropic Response. J. Cardiovasc. Pharmacol. 2018, 72, 136-142. [CrossRef]

35. Ross, S.A.; Rorabaugh, B.R.; Chalothorn, D.; Yun, J.; Gonzalez-Cabrera, P.J.; McCune, D.F.; Piascik, M.T.; Perez, D.M. The $\alpha_{1 \mathrm{~B}}$-adrenergic receptor decreases the inotropic response in the mouse Langendorff heart model. Cardiovasc. Res. 2003, 60, 598-607. [CrossRef] [PubMed]

36. Uchi, J.; Sasaki, H.; Morimoto, S.; Kusakari, Y.; Shinji, H.; Obata, T.; Hongo, K.; Komukai, K.; Kurihara, S. Interaction of $\alpha_{1}$-adrenoceptor subtypes with different $G$ proteins induces opposite effects on cardiac L-type Ca2+ channel. Circ. Res. 2008, 102, 1378-1388. [CrossRef] [PubMed]

37. Cowley, P.M.; Wang, G.; Chang, A.N.; Makwana, O.; Swigart, P.M.; Lovett, D.H.; Stull, J.T.; Simpsom, P.C.; Baker, A.J. The $\alpha_{1 \mathrm{~A}}$-adrenergic receptor subtype mediates increased contraction of failing right ventricular myocardium. Am. J. Physiol. Heart Circ. Physiol. 2015, 309, H888-H896. [CrossRef] [PubMed]

38. Cowley, P.M.; Wang, G.; Joshi, S.; Swigart, P.M.; Lovett, D.H.; Simpson, P.C.; Baker, A.J. $\alpha_{1 \mathrm{~A}}$-Subtype adrenergic agonist therapy for the failing right ventricle. Am. J. Physiol. Heart Circ. Physiol. 2017, 313, H1109-H1118. [CrossRef] [PubMed]

39. Cowley, P.M.; Wang, G.; Swigart, P.M.; Raghunathan, A.; Reddy, N.; Dulam, P.; Lovett, D.H.; Simpson, P.C.; Baker, A.J. Reversal of right ventricular failure by chronic $\alpha_{1 \mathrm{~A}}$-subtype adrenergic agonist therapy. Am. J. Physiol. Heart Circ. Physiol. 2019, 316, H224-H232. [CrossRef] [PubMed]

40. Myagmar, B.E.; Flynn, J.M.; Cowley, P.M.; Swigart, P.M.; Montgomery, M.D.; Thai, K.; Nair, D.; Gupta, R.; Deng, D.X.; Hosoda, C.; et al. Adrenergic Receptors in Individual Ventricular Myocytes: The $\beta_{1}$ and $\alpha_{1 \mathrm{~B}}$ Are in All Cells, the $\alpha_{1 \mathrm{~A}}$ Is in a Subpopulation, and the $\beta_{2}$ and $\beta_{3}$ Are Mostly Absent. Circ. Res. 2017, 120, 1103-1115. [CrossRef] [PubMed]

41. Philipp, M.; Hein, L. Adrenergic receptor knockout mice: Distinct functions of 9 receptor subtypes. Pharmacol. Ther. 2004, 101, 65-74. [CrossRef]

42. Hein, L.; Altman, J.D.; Kobilka, B.K. Two functionally distinct $\alpha_{2}$-adrenergic receptors regulate sympathetic neurotransmission. Nature. 1999, 402, 181-184. [CrossRef]

43. Lymperopoulos, A.; Rengo, G.; Koch, W.J. Adrenal adrenoceptors in heart failure: Fine-tuning cardiac stimulation. Trends Mol. Med. 2007, 13, 503-511. [CrossRef] [PubMed]

44. Brede, M.; Wiesmann, F.; Jahns, R.; Hadamek, K.; Arnolt, C.; Neubauer, S.; Lohse, M.J.; Hein, L. Feedback inhibition of catecholamine release by two different $\alpha_{2}$-adrenoceptor subtypes prevent progression of heart failure. Circulation 2002, 106, 2491-2496. [CrossRef] [PubMed]

45. Bristow, M.R. Mechanistic and clinical rationales for using beta-blockers in heart failure. J. Card. Fail. 2000, 6, 8-14. [PubMed]

46. Todd, G.L.; Baroldi, G.; Pieper, G.M.; Clayton, F.C.; Eliot, R.S. Experimental catecholamine-induced myocardial necrosis. I. Morphology, quantification and regional distribution of acute contraction band lesions. J. Mol. Cell. Cardiol. 1985, 17, 317-338. [CrossRef]

47. Mann, D.L.; Kent, R.L.; Parsons, B.; Cooper, G., 4th. Adrenergic effects on the biology of the adult mammalian cardiocyte. Circulation 1992, 85, 790-804. [CrossRef]

48. Communal, C.; Singh, K.; Pimentel, D.R.; Colucci, W.S. Norepinephrine stimulates apoptosis in adult rat ventricular myocytes by activation of the $\beta$-adrenergic pathway. Circulation 1998, 98, 1329-1334. [CrossRef] [PubMed]

49. Felker, G.M.; O'Connor, C.M. Inotropic therapy for heart failure: An evidence-based approach. Am. Heart J. 2001, $142,393-401$. [CrossRef]

50. Zaugg, M.; Xu, W.; Lucchinetti, E.; Shafiq, S.A.; Jamali, N.Z.; Siddiqui, M.A. $\beta$-adrenergic receptor subtypes differentially affect apoptosis in adult rat ventricular myocytes. Circulation 2000, 102, 344-350. [CrossRef]

51. Ahmet, I.; Krawczyk, M.; Heller, P.; Moon, C.; Lakatta, E.G.; Talan, M.I. Beneficial effects of chronic pharmacological manipulation of $\beta$-adrenoreceptor subtype signaling in rodent dilated ischemic cardiomyopathy. Circulation 2004, 110, 1083-1090. [CrossRef]

52. Ahmet, I.; Krawczyk, M.; Zhu, W.; Woo, A.Y.; Morrell, C.; Poosala, S.; Xiao, R.P.; Lakatta, E.G.; Talan, M.I. Cardioprotective and survival benefits of long-term combined therapy with $\beta_{2}$ adrenoreceptor (AR) agonist and $\beta_{1}$ AR blocker in dilated cardiomyopathy postmyocardial infarction. J. Pharmacol. Exp. Ther. 2008, 325, 491-499. [CrossRef] 
53. Nikolaev, V.O.; Moshkov, A.; Lyon, A.R.; Miragoli, M.; Novak, P.; Paur, H.; Lohse, M.J.; Korchev, Y.E.; Harding, S.E.; Gorelik, J. $\beta_{2}$-adrenergic receptor redistribution in heart failure changes cAMP compartmentation. Science 2010, 327, 1653-1657. [CrossRef] [PubMed]

54. Packer, M.; Bristow, M.R.; Cohn, J.N. The effect of carvedilol on morbidity and mortality in patients with chronic heart failure. U.S. carvedilol heart failure study group. N. Engl. J. Med. 1996, 334, 1349-1355. [CrossRef] [PubMed]

55. Packer, M.; Antonopoulos, G.V.; Berlin, J.A.; Chittams, J.; Konstam, M.A.; Udelson, J.E. Comparative effects of carvedilol and metoprolol on left ventricular ejection fraction in heart failure: Results of a meta-analysis. Am. Heart J. 2001, 141, 899-907. [CrossRef] [PubMed]

56. Erdmann, E.; Lechat, P.; Verkenne, P.; Wiemann, H. Results from post-hoc analyses of the CIBIS II trial: Effect of bisoprolol in high-risk patient groups with chronic heart failure. Eur. J. Heart Fail. 2001, 3, 469-479.

57. Leineweber, K.; Rohe, P.; Beilfuss, A.; Wolf, C.; Sporkmann, H.; Bruck, H.; Jakob, H.G.; Heusch, G.; Philipp, T.; Brodde, O.E. G-protein-coupled receptor kinase activity in human heart failure: Effects of $\beta$-adrenoceptor blockade. Cardiovasc. Res. 2005, 66, 512-519. [CrossRef] [PubMed]

58. Garcia-Prieto, J.; Garcia-Ruiz, J.M.; Sanz-Rosa, D.; Pun, A.; Garcia-Alvarez, A.; Davidson, S.M.; Fernández-Friera, L.; Nuno-Ayala, M.; Fernández-Jiménez, R.; Bernal, J.A.; et al. $\beta_{3}$-adrenergic receptor selective stimulation during ischemia/ reperfusion improves cardiac function in translational models through inhibition of mPTP opening in cardiomyocytes. Basic Res. Cardiol. 2014, 109, 422. [CrossRef]

59. Cannavo, A.; Koch, W.J. Targeting $\beta_{3}$-Adrenergic Receptors in the Heart: Selective Agonism and $\beta$-Blockade. J. Cardiovasc. Pharmacol. 2017, 69, 71-78. [CrossRef] [PubMed]

60. Bristow, M.R.; Ginsburg, R.; Minobe, W.; Cubicciotti, R.S.; Sageman, W.S.; Lurie, K.; Billingham, M.E.; Harrison, D.C.; Stinson, E.B. Decreased catecholamine sensitivity and $\beta$-adrenergic-receptor density in failing human hearts. N. Engl. J. Med. 1982, 307, 205-211. [CrossRef]

61. Hwang, K.C.; Gray, C.D.; Sweet, W.E.; Moravec, C.S.; Im, M.J. $\alpha_{1}$-adrenergic receptor coupling with Gh in the failing human heart. Circulation 1996, 94, 718-726. [CrossRef] [PubMed]

62. Vago, T.; Bevilacqua, M.; Norbiato, G.; Baldi, G.; Chebat, E.; Bertora, P.; Baroldi, R.; Accinni, R. Identification of $\alpha_{1}$-adrenergic receptors on sarcolemma from normal subjects and patients with idiopathic dilated cardiomyopathy: Characteristics and linkage to GTP-binding protein. Circ. Res. 1989, 64, 474-481. [CrossRef]

63. Grigore, A.; Poindexter, B.; Vaughn, W.K.; Nussmeier, N.; Frazier, O.H.; Cooper, J.R.; Gregoric, I.D.; Buja, L.M.; Bick, R.J. Alterations in $\alpha$-adrenoreceptor density and localization after mechanical left ventricular unloading with the Jarvik flowmaker left ventricular assist device. J. Heart Lung Transpl. 2005, 24, 609-613. [CrossRef]

64. Zhao, M.; Hagler, H.K.; Muntz, K.H. Regulation of $\alpha_{1^{-}}, \beta_{1^{-}}$, and $\beta_{2}$-adrenergic receptors in rat heart by norepinephrine. Am. J. Physiol. 1996, 271, H1762-H1768. [PubMed]

65. Limas, C.J.; Limas, C.; Goldenberg, I.F. Intracellular distribution of adrenoceptors in the failing human myocardium. Am. Heart J. 1989, 117, 1310-1316. [CrossRef]

66. Fischer, V.; Gabauer, I.; Tillinger, A.; Novakova, M.; Pechan, I.; Krizanova, O.; Myslivecek, J. Heart adrenoceptor gene expression and binding sites in the human failing heart. Ann. N. Y. Acad. Sci. 2008, 1148, 400-408. [CrossRef]

67. Shi, T.; Moravec, C.S.; Perez, D.M. Novel proteins associated with human dilated cardiomyopathy: Selective reduction in $\alpha_{1 \mathrm{~A}}$-adrenergic receptors and increased desensitization proteins. J. Recept. Signal. Transduct. Res. 2013, 33, 96-106. [CrossRef]

68. Corr, P.B.; Shayman, J.A.; Kramer, J.B.; Kipnis, R.J. Increased $\alpha$-adrenergic receptors in ischemic cat myocardium: A potential mediator of electrophysiological derangements. J. Clin. Investig. 1981, 67, 1232-1236. [CrossRef]

69. Maisel, A.S.; Motulsky, H.J.; Ziegler, M.G.; Insel, P.A. Ischemia- and agonist-induced changes in $\alpha$-and $\beta$-adrenergic receptor traffic in guinea pig hearts. Am. J. Physiol. 1987, 253, H1159-H1166. [CrossRef]

70. Butterfield, M.C.; Chess-Williams, R. Enhanced $\alpha$-adrenoceptor responsiveness and receptor number during global ischaemia in the Langendorff perfused rat heart. Br. J. Pharmacol. 1990, 100, 641-645. [CrossRef]

71. Itaya, T.; Hashimoto, H.; Satoh, R.; Uematsu, T.; Nakashima, M. Increases in $\alpha$ - but not $\beta$-adrenoceptors in hypertrophied non-infarcted cardiac muscles from rats with chronic myocardial infarction. Jpn. J. Pharmacol. 1990, 53, 513-518. [CrossRef] [PubMed]

72. Kurz, T.; Yamada, K.A.; DaTorre, S.D.; Corr, P.B. $\alpha_{1}$-adrenergic system and arrhythmias in ischaemic heart disease. Eur. Heart J. 1991, 12, 88-98. [CrossRef] [PubMed]

73. Eckhart, A.D.; Zhu, Z.; Arendshorst, W.J.; Faber, J.E. Oxygen modulates $\alpha_{1 B}$-adrenergic receptor gene expression by arterial but not venous vascular smooth muscle. Am. J. Physiol. 1996, 271, H1599-H1608. [PubMed]

74. Böhm, M.; Diet, F.; Feiler, G.; Kemkes, B.; Erdmann, E. $\alpha$-adrenoceptors and $\alpha$-adrenoceptor-mediated positive inotropic effects in failing human myocardium. J. Cardiovasc. Pharmacol. 1988, 12, 357-364. [CrossRef] [PubMed]

75. Skomedal, T.; Borthne, K.; Aass, H.; Geiran, O.; Osnes, J.B. Comparison between $\alpha_{1}$ - adrenoceptor-mediated and $\beta$-adrenoceptormediated inotropic components elicited by norepinephrine in failing human ventricular muscle. J. Pharmacol. Exp. Ther. 1997, 280, 721-729.

76. Sjaastad, I.; Schiander, I.; Sjetnan, A.; Qvigstad, E.; Bøkenes, J.; Sandnes, D.; Osnes, J.-B.; Sejersted, O.M.; Skomedal, T. Increased contribution of $\alpha_{1}$ - vs. $\beta$-adrenoceptor-mediated inotropic response in rats with congestive heart failure. Acta Physiol. Scand. 2003, 177, 449-458. [CrossRef] 
77. Du, X.J.; Fang, L.; Gao, X.M.; Kiriazis, H.; Feng, X.; Hotchkin, E.; Finch, A.M.; Chaulet, H.; Graham, R.M. Genetic enhancement of ventricular contractility protects against pressure-overload-induced cardiac dysfunction. J. Mol. Cell Cardiol. 2004, 37, 979-987. [CrossRef] [PubMed]

78. Du, X.J.; Gao, X.M.; Kiriazis, H.; Moore, X.L.; Ming, Z.; Su, Y.; Finch, A.M.; Hannan, R.A.; Dart, A.M.; Graham, R.M. Transgenic $\alpha_{1 \mathrm{~A}}$-adrenergic activation limits post-infarct ventricular remodeling and dysfunction and improves survival. Cardiovasc. Res. 2006, 71, 735-743. [CrossRef]

79. Beak, J.; Huang, W.; Parker, J.S.; Hicks, S.T.; Patterson, C.; Simpson, P.C.; Ma, A.; Jin, J.; Jensen, B.C. An Oral Selective $\alpha_{1 A^{-}}$ Adrenergic Receptor Agonist Prevents Doxorubicin Cardiotoxicity. JACC Basic Transl. Sci. 2017, 2, 39-53. [CrossRef]

80. Montgomery, M.D.; Chan, T.; Swigart, P.M.; Myagmar, B.E.; Dash, R.; Simpson, P.C. An $\alpha_{1 A}$-Adrenergic Receptor Agonist Prevents Acute Doxorubicin Cardiomyopathy in Male Mice. PLoS ONE 2017, 12, e0168409. [CrossRef]

81. Akhter, S.A.; Milano, C.A.; Shotwell, K.F.; Cho, M.C.; Rockman, H.A.; Lefkowitz, R.J.; Koch, W.J. Transgenic mice with cardiac overexpression of $\alpha_{1 B}$-adrenergic receptors. In vivo $\alpha_{1}$-adrenergic receptor-mediated regulation of $\beta$-adrenergic signaling. J. Biol. Chem. 1997, 272, 21253-21259. [CrossRef]

82. Grupp, I.L.; Lorenz, J.N.; Walsh, R.A.; Boivin, G.P.; Rindt, H. Overexpression of $\alpha_{1 \mathrm{~B}}$-adrenergic receptor induces left ventricular dysfunction in the absence of hypertrophy. Am. J. Physiol. 1998, 275, H1338-H1350. [CrossRef]

83. Lemire, I.; Ducharme, A.; Tardif, J.C.; Poulin, F.; Jones, L.R.; Allen, B.G.; Hebert, T.E.; Rindt, H. Cardiac-directed overexpression of wild-type $\alpha_{1 \mathrm{~B}}$-adrenergic receptor induces dilated cardiomyopathy. Am. J. Physiol. Heart Circ. Physiol. 2001, 281, H931-H938. [CrossRef] [PubMed]

84. Wang, B.H.; Du, X.J.; Autelitano, D.J.; Milano, C.A.; Woodcock, E.A. Adverse effects of constitutively active $\alpha_{1 \mathrm{~B}}-\mathrm{adrenergic}$ receptors after pressure overload in mouse hearts. Am. J. Physiol. Heart Circ. Physiol. 2000, 279, H1079-H1086. [CrossRef]

85. Elia, M. Organ and tissue contribution to metabolic rate. In Energy Metabolism: Tissue Determinants and Cellular Corollaries; Kinney, J.M., Tucker, H.N., Eds.; Raven Press: New York, NY, USA, 1992; pp. 61-80.

86. Neubauer, S. The failing heart-An engine out of fuel. N. Engl. J. Med. 2007, 356, 1140-1151. [CrossRef]

87. Olson, R.E.; Schwartz, W.B. Myocardial metabolism in congestive heart failure. Medicine 1951, 30, 21-41. [CrossRef] [PubMed]

88. Cheng, M.L.; Wang, C.H.; Shiao, M.S.; Liu, M.H.; Huang, Y.Y.; Huang, C.Y.; Mao, C.-T.; Lin, J.-F.; Ho, H.-Y.; Yang, N.-I. Metabolic disturbances identified in plasma are associated with outcomes in patients with heart failure: Diagnostic and prognostic value of metabolomics. J. Am. Coll. Cardiol. 2015, 65, 1509-1520. [CrossRef] [PubMed]

89. Peoples, J.; Maxmillian, T.; Le, Q.; Nadtochiy, S.M.; Brookes, P.S.; Porter, G.A., Jr.; Davidson, V.L.; Ebert, S.N. Metabolomics reveals critical adrenergic regulatory checkpoints in glycolysis and pentose-phosphate pathways in embryonic heart. J. Biol. Chem. 2018, 293, 6925-6941. [CrossRef]

90. Becker, C.; Sevilla, L.; Tomas, E.; Palacin, M.; Zorzano, A.; Fischer, Y. The endosomal compartment is an insulin-sensitive recruitment site for GLUT4 and GLUT1 glucose transporters in cardiac myocytes. Endocrinology 2001, 142, 5267-5276. [CrossRef]

91. Depré, C.; Rider, M.H.; Hue, L. Mechanisms of control of heart glycolysis. Eur. J. Biochem. 1998, 258, 277-290. [CrossRef]

92. Stanton, R.C. Glucose-6-phosphate dehydrogenase, NADPH, and cell survival. Iubmb Life 2012, 64, 362-369. [CrossRef] [PubMed]

93. Jain, M.; Brenner, D.A.; Cui, L.; Lim, C.C.; Wang, B.; Pimentel, D.R.; Koh, S.; Sawyer, D.B.; Leopold, J.A.; Handy, D.E.; et al. Glucose-6-phosphate dehydrogenase modulates cytosolic redox status and contractile phenotype in adult cardiomyocytes. Circ. Res. 2003, 93, e9-e16. [CrossRef] [PubMed]

94. Turrens, J.F.; Alexandre, A.; Lehninger, A.L. Ubisemiquinone is the electron donor for superoxide formation by complex III of heart mitochondria. Arch. Biochem. Biophys. 1985, 237, 408-414. [CrossRef]

95. Turrens, J.F. Superoxide production by the mitochondrial respiratory chain. Biosci. Rep. 1997, 17, 3-8. [CrossRef]

96. Viola, H.M.; Hool, L.C. Qo site of mitochondrial complex III is the source of increased superoxide after transient exposure to hydrogen peroxide. J. Mol. Cell. Cardiol. 2010, 49, 875-885. [CrossRef]

97. Turrens, J.F. Mitochondrial formation of reactive oxygen species. J. Physiol. 2003, 552, 335-344. [CrossRef]

98. Belch, J.J.; Bridges, A.B.; Scott, N.; Chopra, M. Oxygen free radicals and congestive heart failure. Br. Heart J. 1991, 65, 245-248. [CrossRef]

99. Hill, M.F.; Singal, P.K. Right and left myocardial antioxidant responses during heart failure subsequent to myocardial infarction. Circulation 1997, 96, 2414-2420. [CrossRef]

100. Mallat, Z.; Philip, I.; Lebret, M.; Chatel, D.; Maclouf, J.; Tedgui, A. Elevated levels of 8-iso-prostaglandin F2alpha in pericardial fluid of patients with heart failure: A potential role for in vivo oxidant stress in ventricular dilatation and progression to heart failure. Circulation 1998, 97, 1536-1539. [CrossRef]

101. Nakamura, K.; Kusano, K.; Nakamura, Y.; Kakishita, M.; Ohta, K.; Nagase, S.; Yamamoto, M.; Miyaji, K.; Saito, H.; Morita, H.; et al. Carvedilol decreases elevated oxidative stress in human failing myocardium. Circulation 2002, 105, 2867-2871. [CrossRef]

102. Sam, F.; Kerstetter, D.L.; Pimental, D.R.; Mulukutla, S.; Tabaee, A.; Bristow, M.R.; Colucci, W.S.; Sawyer, D.B. Increased reactive oxygen species production and functional alterations in antioxidant enzymes in human failing myocardium. J. Card. Fail. 2005, 11, 473-480. [CrossRef]

103. Sheeran, F.L.; Pepe, S. Posttranslational modifications and dysfunction of mitochondrial enzymes in human heart failure. Am. J. Physiol. Endocrinol. Metab. 2016, 311, E449-E460. [CrossRef] [PubMed] 
104. Jain, M.; Cui, L.; Brenner, D.A.; Wang, B.; Handy, D.E.; Leopold, J.A.; Loscalzo, J.; Apstein, C.S.; Liao, R. Increased myocardial dysfunction after ischemia-reperfusion in mice lacking glucose-6-phosphate dehydrogenase. Circulation 2004, 109, 898-903. [CrossRef]

105. Long, W.K.; Wilson, S.W.; Frenkel, E.P. Associations between red cell glucose-6-phosphate dehydrogenase variants and vascular diseases. Am. J. Hum. Genet. 1967, 19, 35-53. [PubMed]

106. Hecker, P.A.; Lionetti, V.; Ribeiro, R.F., Jr.; Rastogi, S.; Brown, B.H.; O'Connell, K.A.; Cox, J.W.; Shekar, K.C.; Gamble, D.M.; Sabbah, H.N.; et al. Glucose 6-phosphate dehydrogenase deficiency increases redox stress and moderately accelerates the development of heart failure. Circ. Heart Fail. 2013, 6, 118-126. [CrossRef] [PubMed]

107. Badolia, R.; Ramadurai, D.K.A.; Abel, E.D.; Ferrin, P.; Taleb, I.; Shankar, T.S.; Krokidi, A.T.; Navankasattusas, S.; McKellar, S.H.; Yin, M.; et al. The Role of Nonglycolytic Glucose Metabolism in Myocardial Recovery Upon Mechanical Unloading and Circulatory Support in Chronic Heart Failure. Circulation 2020, 142, 259-274. [CrossRef] [PubMed]

108. Diakos, N.A.; Navankasattusas, S.; Abel, E.D.; Rutter, J.; McCreath, L.; Ferrin, P.; McKellar, S.H.; Miller, D.V.; Park, S.Y.; Richardson, R.S.; et al. Evidence of Glycolysis Up-Regulation and Pyruvate Mitochondrial Oxidation Mismatch During Mechanical Unloading of the Failing Human Heart: Implications for Cardiac Reloading and Conditioning. JACC Basic Transl. Sci. 2016, 1, 432-444. [CrossRef]

109. Lei, B.; Lionetti, V.; Young, M.E.; Chandler, M.P.; d'Agostino, C.; Kang, E.; Altarejos, M.; Matsuo, K.; Hintze, T.H.; Stanley, W.C.; et al. Paradoxical downregulation of the glucose oxidation pathway despite enhanced flux in severe heart failure. J. Mol. Cell. Cardiol. 2004, 36, 567-576. [CrossRef]

110. Razeghi, P.; Young, M.E.; Alcorn, J.L.; Moravec, C.S.; Frazier, O.H.; Taegtmeyer, H. Metabolic gene expression in fetal and failing human heart. Circulation 2001, 104, 2923-2931. [CrossRef]

111. Gupte, S.A.; Levine, R.J.; Gupte, R.S.; Young, M.E.; Lionetti, V.; Labinskyy, V.; Floyd, B.C.; Ojaimi, C.; Bellomo, M.; Wolin, M.S.; et al. Glucose-6-phosphate dehydrogenase-derived NADPH fuels superoxide production in the failing heart. J. Mol. Cell. Cardiol. 2006, 41, 340-349. [CrossRef]

112. Gupte, R.S.; Vijay, V.; Marks, B.; Levine, R.J.; Sabbah, H.N.; Wolin, M.S.; Recchia, F.A.; Gupte, S.A. Upregulation of glucose-6phosphate dehydrogenase and $\mathrm{NAD}(\mathrm{P}) \mathrm{H}$ oxidase activity increases oxidative stress in failing human heart. J. Card. Fail. 2007, 13, 497-506. [CrossRef]

113. Serpillon, S.; Floyd, B.C.; Gupte, R.S.; George, S.; Kozicky, M.; Neito, V.; Recchia, F.; Stanley, W.; Wolin, M.S.; Gupte, S.A. Superoxide production by $\mathrm{NAD}(\mathrm{P}) \mathrm{H}$ oxidase and mitochondria is increased in genetically obese and hyperglycemic rat heart and aorta before the development of cardiac dysfunction. The role of glucose-6-phosphate dehydrogenase-derived NADPH. Am. J. Physiol. Heart Circ. Physiol. 2009, 297, H153-H162. [CrossRef]

114. Vimercati, C.; Qanud, K.; Mitacchione, G.; Sosnowska, D.; Ungvari, Z.; Sarnari, R.; Mania, D.; Patel, N.; Hintze, T.H.; Gupte, S.; et al. Beneficial effects of acute inhibition of the oxidative pentose phosphate pathway in the failing heart. Am. J. Physiol. Heart Circ. Physiol. 2014, 306, H709-H717. [CrossRef]

115. Cocco, P.; Todde, P.; Fornera, S.; Manca, M.B.; Manca, P.; Sias, A.R. Mortality in a cohort of men expressing the glucose-6-phosphate dehydrogenase deficiency. Blood 1998, 91, 706-709. [CrossRef]

116. Meloni, L.; Manca, M.R.; Loddo, I.; Cioglia, G.; Cocco, P.; Schwartz, A.; Muntoni, S.; Muntoni, S. Glucose-6-phosphate dehydrogenase deficiency protects against coronary heart disease. J. Inherit. Metab. Dis. 2008, 31, 412-417. [CrossRef]

117. Sansbury, B.E.; DeMartino, A.M.; Xie, Z.; Brooks, A.C.; Brainard, R.E.; Watson, L.J.; DeFilippis, A.P.; Cummins, T.D.; Harbeson, M.A.; Brittian, K.R.; et al. Metabolomic analysis of pressure-overloaded and infarcted mouse hearts. Circ. Heart Fail. 2014, 7, 634-642. [CrossRef]

118. Contaifer, D., Jr.; Buckley, L.F.; Wohlford, G.; Kumar, N.G.; Morriss, J.M.; Ranasinghe, A.D.; Carbone, S.; Canada, J.M.; Trankle, C.; Abbate, A.; et al. Metabolic modulation predicts heart failure tests performance. PLoS ONE 2019, 14, e0218153. [CrossRef] [PubMed]

119. World Health Organization Working Group. Glucose-6-phosphate dehydrogenase deficiency. WHO Working Group. Bull. World Health Organ. 1989, 67, 601-611.

120. Cappellini, M.D.; Fiorelli, G. Glucose-6-phosphate dehydrogenase deficiency. Lancet 2008, 371, 64-74. [CrossRef]

121. Luzzatto, L. Glucose-6-phosphate dehydrogenase deficiency. Advanced Medicine-Twelve. In Proceedings of the Conference Held at the Royal College of Physicians of London, Churchill Livingstone, UK, 11-14 February 1986.

122. Opie, L.H. Metabolism of the heart in health and disease. I. Am. Heart J. 1968, 76, 685-698. [CrossRef]

123. Opie, L.H. Metabolism of the heart in health and disease. II. Am. Heart J. 1969, 77, 100-122. [CrossRef]

124. Neely, J.R.; Morgan, H.E. Relationship between carbohydrate and lipid metabolism and the energy balance of heart muscle. Annu. Rev. Physiol. 1974, 36, 413-459. [CrossRef]

125. Lopaschuk, G.D.; Ussher, J.R.; Folmes, C.D.; Jaswal, J.S.; Stanley, W.C. Myocardial fatty acid metabolism in health and disease. Physiol. Rev. 2010, 90, 207-258. [CrossRef] [PubMed]

126. Stanley, W.C.; Recchia, F.A.; Lopaschuk, G.D. Myocardial substrate metabolism in the normal and failing heart. Physiol. Rev. 2005, 85, 1093-1129. [CrossRef] [PubMed]

127. Koonen, D.P.; Glatz, J.F.; Bonen, A.; Luiken, J.J. Long-chain fatty acid uptake and FAT/CD36 translocation in heart and skeletal muscle. Biochim. Biophys. Acta 2005, 3, 163-180. [CrossRef] [PubMed] 
128. McGarry, J.D.; Brown, N.F. The mitochondrial carnitine palmitoyltransferase system. From concept to molecular analysis. Eur. J. Biochem. 1997, 244, 1-14. [CrossRef]

129. Ramsay, R.R.; Gandour, R.D.; van der Leij, F.R. Molecular enzymology of carnitine transfer and transport. Biochim. Biophys. Acta 2001, 1546, 21-43. [CrossRef]

130. Conway, M.A.; Allis, J.; Ouwerkerk, R.; Niioka, T.; Rajagopalan, B.; Radda, G.K. Detection of low phosphocreatine to ATP ratio in failing hypertrophied human myocardium by 31P magnetic resonance spectroscopy. Lancet 1991, 338, 973-976. [CrossRef]

131. Beer, M.; Seyfarth, T.; Sandstede, J.; Landschütz, W.; Lipke, C.; Köstler, H.; von Kienlin, M.; Harre, K.; Hahn, D.; Neubauer, S. Absolute concentrations of high-energy phosphate metabolites in normal, hypertrophied, and failing human myocardium measured noninvasively with (31)P-SLOOP magnetic resonance spectroscopy. J. Am. Coll. Cardiol. 2002, 40, 1267-1274. [CrossRef]

132. Tian, R.; Nascimben, L.; Kaddurah-Daouk, R.; Ingwall, J.S. Depletion of energy reserve via the creatine kinase reaction during the evolution of heart failure in cardiomyopathic hamsters. J. Mol. Cell. Cardiol. 1996, 28, 755-765. [CrossRef]

133. Piacentino, V., III; Weber, C.R.; Chen, X.; Weisser-Thomas, J.; Margulies, K.B.; Bers, D.M.; Houser, S.R. Cellular basis of abnormal calcium transients of failing human ventricular myocytes. Circ. Res. 2003, 92, 651-658. [CrossRef]

134. Noland, R.C.; Koves, T.R.; Seiler, S.E.; Lum, H.; Lust, R.M.; Ilkayeva, O.; Stevens, R.D.; Hegardt, F.G.; Muoio, D.M. Carnitine insufficiency caused by aging and overnutrition compromises mitochondrial performance and metabolic control. J. Biol. Chem. 2009, 284, 22840-22852. [CrossRef]

135. Koves, T.R.; Ussher, J.R.; Noland, R.C.; Slentz, D.; Mosedale, M.; Ilkayeva, O.; Bain, J.; Stevens, R.; Dyck, J.R.; Newgard, C.B.; et al. Mitochondrial overload and incomplete fatty acid oxidation contribute to skeletal muscle insulin resistance. Cell. Metab. 2008, 7, 45-56. [CrossRef] [PubMed]

136. Akhmedov, A.T.; Rybin, V.; Marin-Garcia, J. Mitochondrial oxidative metabolism and uncoupling proteins in the failing heart. Heart Fail. Rev. 2015, 20, 227-249. [CrossRef] [PubMed]

137. Steinberg, B.A.; Zhao, X.; Heidenreich, P.A.; Peterson, E.D.; Bhatt, D.L.; Cannon, C.P.; Hernandez, A.F.; Fonarow, G.C.; Get With the Guidelines Scientific Advisory Committee and Investigators. Trends in patients hospitalized with heart failure and preserved left ventricular ejection fraction: Prevalence, therapies, and outcomes. Circulation 2012, 126, 65-75. [CrossRef]

138. Li, X. SIRT1 and energy metabolism. Acta Biochim. Biophys. Sin. 2013, 45, 51-60. [CrossRef] [PubMed]

139. Dorn, G.W.; Vega, R.B.; Kelly, D.P. Mitochondrial biogenesis and dynamics in the developing and diseased heart. Genes Dev. 2015, 29, 1981-1991. [CrossRef]

140. Lu, T.M.; Tsai, J.Y.; Chen, Y.C.; Huang, C.Y.; Hsu, H.L.; Weng, C.F.; Shih, C.C.; Hsu, C.P. Downregulation of Sirt1 as aging change in advanced heart failure. J. Biomed. Sci. 2014, 21, 57. [CrossRef] [PubMed]

141. Santulli, G.; Nakashima, R.; Yuan, Q.; Marks, A.R. Intracellular calcium release channels: An update. J. Physiol. 2017, 595, 3041-3051. [CrossRef]

142. Bugger, H.; Schwarzer, M.; Chen, D.; Schrepper, A.; Amorim, P.A.; Schoepe, M.; Nguyen, T.D.; Mohr, F.W.; Khalimonchuk, O.; Weimer, B.C.; et al. Proteomic remodelling of mitochondrial oxidative pathways in pressure overload-induced heart failure. Cardiovasc. Res. 2010, 85, 376-384. [CrossRef]

143. Doenst, T.; Pytel, G.; Schrepper, A.; Amorim, P.; Farber, G.; Shingu, Y.; Mohr, F.W.; Schwarzer, M. Decreased rates of substrate oxidation ex vivo predict the onset of heart failure and contractile dysfunction in rats with pressure overload. Cardiovasc. Res. 2010, 86, 461-470. [CrossRef]

144. Osorio, J.C.; Stanley, W.C.; Linke, A.; Castellari, M.; Diep, Q.N.; Panchal, A.R.; Hintze, T.H.; Lopaschuk, G.D.; Recchia, F.A. Impaired myocardial fatty acid oxidation and reduced protein expression of retinoid $\mathrm{X}$ receptor-alpha in pacing-induced heart failure. Circulation 2002, 106, 606-612. [CrossRef] [PubMed]

145. Qanud, K.; Mamdani, M.; Pepe, M.; Khairallah, R.J.; Gravel, J.; Lei, B.; Gupte, S.A.; Sharov, V.G.; Sabbah, H.N.; Stanley, W.C.; et al. Reverse changes in cardiac substrate oxidation in dogs recovering from heart failure. Am. J. Physiol. Heart Circ. Physiol. 2008, 295, H2098-H2105. [CrossRef]

146. Neglia, D.; De Caterina, A.; Marraccini, P.; Natali, A.; Ciardetti, M.; Vecoli, C.; Gastaldelli, A.; Ciociaro, D.; Pellegrini, P.; Testa, R.; et al. Impaired myocardial metabolic reserve and substrate selection flexibility during stress in patients with idiopathic dilated cardiomyopathy. Am. J. Physiol. Heart Circ. Physiol. 2007, 293, H3270-H3278. [CrossRef]

147. Ingwall, J.S. On substrate selection for ATP synthesis in the failing human myocardium. Am. J. Physiol. Heart Circ. Physiol. 2007, 293, H3225-H3226. [CrossRef] [PubMed]

148. Zordoky, B.N.; Sung, M.M.; Ezekowitz, J.; Mandal, R.; Han, B.; Bjorndahl, T.C.; Bouatra, S.; Anderson, T.; Oudit, G.Y.; Wishart, D.S.; et al. Metabolomic fingerprint of heart failure with preserved ejection fraction. PLOS ONE 2015, 10, e0124844.

149. Hunter, W.G.; Kelly, J.P.; McGarrah, R.W., III; Khouri, M.G.; Craig, D.; Haynes, C.; Ilkayeva, O.; Stevens, R.D.; Bain, J.R.; Muehlbauer, M.J.; et al. Metabolomic Profiling Identifies Novel Circulating Biomarkers of Mitochondrial Dysfunction Differentially Elevated in Heart Failure with Preserved Versus Reduced Ejection Fraction: Evidence for Shared Metabolic Impairments in Clinical Heart Failure. J. Am. Heart Assoc. 2016, 5, e003190. [CrossRef] [PubMed]

150. De Jong, K.A.; Lopaschuk, G.D. Complex Energy Metabolic Changes in Heart Failure with Preserved Ejection Fraction and Heart Failure with Reduced Ejection Fraction. Can. J. Cardiol. 2017, 33, 860-871. [CrossRef]

151. Senni, M.; Redfield, M.M. Heart failure with preserved systolic function: A different natural history? J. Am. Coll. Cardiol. 2001, 38, 1277-1282. [CrossRef] 
152. Hogg, K.; Swedberg, K.; McMurray, J. Heart failure with preserved left ventricular systolic function; epidemiology, clinical characteristics, and prognosis. J. Am. Coll. Cardiol. 2004, 43, 317-327. [CrossRef]

153. Owan, T.E.; Hodge, D.O.; Herges, R.M.; Jacobsen, S.J.; Roger, V.L.; Redfield, M.M. Trends in prevalence and outcome of heart failure with preserved ejection fraction. N. Engl. J. Med. 2006, 355, 251-259. [CrossRef]

154. Davila-Roman, V.G.; Vedala, G.; Herrero, P.; de las Fuentes, L.; Rogers, J.G.; Kelly, D.P.; Gropler, R.J. Altered myocardial fatty acid and glucose metabolism in idiopathic dilated cardiomyopathy. J. Am. Coll. Cardiol. 2002, 40, 271-277. [CrossRef]

155. Tuunanen, H.; Engblom, E.; Naum, A.; Någren, K.; Hesse, B.; Airaksinen, K.E.; Nuutila, P.; Iozzo, P.; Ukkonen, H.; Opie, L.H.; et al. Free fatty acid depletion acutely decreases cardiac work and efficiency in cardiomyopathic heart failure. Circulation 2006, 114, 2130-2137. [CrossRef] [PubMed]

156. Kato, T.; Niizuma, S.; Inuzuka, Y.; Kawashima, T.; Okuda, J.; Tamaki, Y.; Iwanaga, Y.; Narazaki, M.; Matsuda, T.; Soga, T.; et al. Analysis of metabolic remodeling in compensated left ventricular hypertrophy and heart failure. Circ. Heart Fail. 2010, 3, 420-430. [CrossRef] [PubMed]

157. Christe, M.E.; Rodgers, R.L. Cardiac glucose and fatty acid oxidation in the streptozotocin-induced diabetic spontaneously hypertensive rat. Hypertension 1995, 25, 235-241. [CrossRef] [PubMed]

158. Abel, E.D.; Kaulbach, H.C.; Tian, R.; Hopkins, J.C.; Duffy, J.; Doetschman, T.; Minnemann, T.; Boers, M.E.; Hadro, E.; ObersteBerghaus, C.; et al. Cardiac hypertrophy with preserved contractile function after selective deletion of GLUT4 from the heart. J. Clin. Investig. 1999, 104, 1703-1714. [CrossRef] [PubMed]

159. Lopaschuk, G.D.; Folmes, C.D.; Stanley, W.C. Cardiac energy metabolism in obesity. Circ. Res. 2007, 101, 335-347. [CrossRef] [PubMed]

160. Mori, J.; Basu, R.; McLean, B.A.; Das, S.K.; Zhang, L.; Patel, V.B.; Wagg, C.S.; Kassiri, Z.; Lopaschuk, G.D.; Oudit, G.Y. Agonistinduced hypertrophy and diastolic dysfunction are associated with selective reduction in glucose oxidation. A metabolic contribution to heart failure with normal ejection fraction. Circ. Heart Fail. 2012, 5, 493-503. [CrossRef]

161. Mori, J.; Alrob, O.A.; Wagg, C.S.; Harris, R.A.; Lopaschuk, G.D.; Oudit, G.Y. ANG II causes insulin resistance and induces cardiac metabolic switch and inefficiency: A critical role of Pdkam. J. Physiol. Heart Circ. Physiol. 2013, 304, H1103-H1113. [CrossRef]

162. Zhang, L.; Jaswal, J.S.; Ussher, J.R.; Sankaralingam, S.; Wagg, L.; Zaugg, M.; Lopaschuk, G.D. Cardiac insulin-resistance and decreased mitochondrial energy production precede the development of systolic heart failure after pressure-overload hypertrophy. Circ. Heart Fail. 2013, 6, 1039-1048. [CrossRef] [PubMed]

163. Sankaralingam, S.; Abo Alrob, O.; Zhang, L.; Jaswal, J.S.; Wagg, C.S.; Fukushima, A.; Padwal, R.S.; Johnstone, D.E.; Sharma, A.M.; Lopaschuk, G.D. Lowering body weight in obese mice with diastolic heart failure improves cardiac insulin sensitivity and function: Implications for the obesity paradox. Diabetes 2015, 64, 1643-1657. [CrossRef] [PubMed]

164. Lionetti, V.; Stanley, W.C.; Recchia, F.A. Modulating fatty acid oxidation in heart failure. Cardiovasc. Res. 2011, 90, 202-209. [CrossRef] [PubMed]

165. Fillmore, N.; Mori, J.; Lopaschuk, G.D. Mitochondrial fatty acid oxidation alterations in heart failure, ischaemic heart disease and diabetic cardiomyopathy. Br. J. Pharmacol. 2014, 171, 2080-2090. [CrossRef] [PubMed]

166. Sorokina, N.; O’Donnell, J.M.; McKinney, R.D.; Pound, K.M.; Woldegiorgis, G.; LaNoue, K.F.; Ballal, K.; Taegtmeyer, H.; Buttrick, P.M.; Lewandowski, E.D. Recruitment of compensatory pathways to sustain oxidative flux with reduced carnitine palmitoyltransferase I activity characterizes inefficiency in energy metabolism in hypertrophied hearts. Circulation 2007, 115, 2033-2041. [CrossRef]

167. Jarreta, D.; Orus, J.; Barrientos, A.; Miro, O.; Roig, E.; Heras, M.; Moraes, C.T.; Cardellach, F.; Casademont, J. Mitochondrial function in heart muscle from patients with idiopathic dilated cardiomyopathy. Cardiovasc. Res. 2000, 45, 860-865. [CrossRef]

168. Quigley, A.F.; Kapsa, R.M.; Esmore, D.; Hale, G.; Byrne, E. Mitochondrial respiratory chain activity in idiopathic dilated cardiomyopathy. J. Card. Fail. 2000, 6, 47-55. [CrossRef]

169. Sheeran, F.L.; Pepe, S. Energy deficiency in the failing heart: Linking increased reactive oxygen species and disruption of oxidative phosphorylation rate. Biochim. Biophys. Acta 2006, 1757, 543-552. [CrossRef]

170. Scheubel, R.J.; Tostlebe, M.; Simm, A.; Rohrbach, S.; Prondzinsky, R.; Gellerich, F.N.; Silber, R.E.; Holtz, J. Dysfunction of mitochondrial respiratory chain complex I in human failing myocardium is not due to disturbed mitochondrial gene expression. J. Am. Coll. Cardiol. 2002, 40, 2174-2181. [CrossRef]

171. Kjekshus, J.K.; Mjos, O.D. Effect WI inhibition of lipolysis on myocardial oxygen consumption in the presence of isoproterenol. J. Clin. Investig. 1972, 51, 1767-1776. [CrossRef]

172. Mjos, O.D. Effect of inhibition of lipolysis on myocardial oxygen consumption in the presence of isoproterenol. J. Clin. Investig. 1971, 50, 1869-1873. [CrossRef]

173. Liu, B.; Clanachan, A.S.; Schulz, R.; Lopaschuk, G.D. Cardiac efficiency is improved after ischemia by altering both the source and fate of protons. Circ. Res. 1996, 79, 940-948. [CrossRef] [PubMed]

174. Liu, Q.; Docherty, J.C.; Rendell, J.C.T.; Clanachan, A.S.; Lopaschuk, G.D. High levels of fatty acids delay the recovery of intracellular $\mathrm{pH}$ and cardiac efficiency in post-ischemic hearts by inhibiting glucose oxidation. J. Am. Coll. Cardiol. 2002, 39, 718-725. [CrossRef]

175. Folmes, C.D.; Clanachan, A.S.; Lopaschuk, G.D. Fatty acids attenuate insulin regulation of $5^{\prime}$-AMP-activated protein kinase and insulin cardioprotection after ischemia. Circ. Res. 2006, 99, 61-68. [CrossRef]

176. Vogel, S.; Sperelakis, N. Blockade of myocardial slow inward current at low pH. Am. J. Phys. 1977, 233, C99-C103. [CrossRef] 
177. Steenbergen, C.; Deleeuw, G.; Rich, T.; Williamson, J.R. Effects of acidosis and ischemia on contractility and intracellular pH of rat heart. Circ. Res. 1977, 41, 849-858. [CrossRef]

178. Beanlands, R.S.B.; Armstrong, W.F.; Hicks, R.J.; Nicklas, J.; Moore, C.; Hutchins, G.D.; Wolpers, H.G.; Schwaiger, M. The effects of afterload reduction on myocardial carbon 11-labeled acetate kinetics and noninvasively estimated mechanical efficiency in patients with dilated cardiomyopathy. J. Nucl. Cardiol. 1994, 1, 3-16. [CrossRef]

179. Masoud, W.G.; Ussher, J.R.; Wang, W.; Jaswal, J.S.; Wagg, C.S.; Dyck, J.R.; Lygate, C.A.; Neubauer, S.; Clanachan, A.S.; Lopaschuk, G.D. Failing mouse hearts utilize energy inefficiently and benefit from improved coupling of glycolysis and glucose oxidation. Cardiovasc. Res. 2014, 101, 30-38. [CrossRef] [PubMed]

180. Lopaschuk, G.D.; Barr, R.; Thomas, P.D.; Dyck, J.R. Beneficial effects of trimetazidine in ex vivo working ischemic hearts are due to a stimulation of glucose oxidation secondary to inhibition of long-chain 3-ketoacyl coenzyme a thiolase. Circ. Res. 2003, 93, e33-e37. [CrossRef] [PubMed]

181. Dyck, J.R.; Cheng, J.F.; Stanley, W.C.; Barr, R.; Chandler, M.P.; Brown, S.; Wallace, D.; Arrhenius, T.; Harmon, C.; Yang, G.; et al. Malonyl coenzyme a decarboxylase inhibition protects the ischemic heart by inhibiting fatty acid oxidation and stimulating glucose oxidation. Circ. Res. 2004, 94, e78-e84. [CrossRef] [PubMed]

182. Dyck, J.R.; Hopkins, T.A.; Bonnet, S.; Michelakis, E.D.; Young, M.E.; Watanabe, M.; Kawase, Y.; Jishage, K.; Lopaschuk, G.D. Absence of malonyl coenzyme A decarboxylase in mice increases cardiac glucose oxidation and protects the heart from ischemic injury. Circulation 2006, 114, 1721-1728. [CrossRef] [PubMed]

183. Ussher, J.R.; Wang, W.; Gandhi, M.; Keung, W.; Samokhvalov, V.; Oka, T.; Wagg, C.S.; Jaswal, J.S.; Harris, R.A.; Clanachan, A.S.; et al. Stimulation of glucose oxidation protects against acute myocardial infarction and reperfusion injury. Cardiovasc. Res. 2012, 94, 359-369. [CrossRef] [PubMed]

184. Fukushima, A.; Milner, K.; Gupta, A.; Lopaschuk, G.D. Myocardial Energy Substrate Metabolism in Heart Failure: From Pathways to Therapeutic Targets. Curr. Pharm. Des. 2015, 21, 3654-3664. [CrossRef] [PubMed]

185. Fillmore, N.; Levasseur, J.L.; Fukushima, A.; Wagg, C.S.; Wang, W.; Dyck, J.R.B.; Lopaschuk, G.D. Uncoupling of glycolysis from glucose oxidation accompanies the development of heart failure with preserved ejection fraction. Mol. Med. 2018, 24, 3. [CrossRef]

186. Li, T.; Xu, J.; Qin, X.; Hou, Z.; Guo, Y.; Liu, Z.; Wu, J.; Zheng, H.; Zhang, X.; Gao, F. Glucose oxidation positively regulates glucose uptake and improves cardiac function recovery after myocardial reperfusion. Am. J. Physiol. Endocrinol. Metab. 2017, 313, E577-E585. [CrossRef]

187. Wargovich, T.J.; MacDonald, R.G.; Hill, J.A.; Feldman, R.L.; Stacpoole, P.W.; Pepine, C.J. Myocardial metabolic and hemodynamic effects of dichloroacetate in coronary artery disease. Am. J. Cardiol. 1988, 61, 65-70. [CrossRef]

188. McGarry, J.D.; Takabayashi, Y.; Foster, D.W. The role of malonyl-CoA in the coordination of fatty acid synthesis and oxidation in isolated rat hepatocytes. J. Biol. Chem. 1978, 253, 8294-8300. [CrossRef]

189. Lopaschuk, G.D.; Wal, 1.S.R.; Olley, P.M.; Davies, N.J. Etomoxir, a carnitine palmitoyltransferase I inhibitor, protects hearts from fatty acid-induced ischemic injury independent of changes in long chain acylcarnitine. Circ. Res. 1988, 63, 1036-1043. [CrossRef]

190. Wall, S.R.; Lopaschuk, G.D. Glucose oxidation rates in fatty acid-perfused isolated working hearts from diabetic rats. Biochim. Biophys. Acta 1989, 1006, 97-103. [CrossRef]

191. Schmidt-Schweda, S.; Holubarsch, C. First clinical trial with etomoxir in patients with chronic congestive heart failure. Clin. Sci. 2000, 99, 27-35. [CrossRef]

192. Lee, L.; Campbell, R.; Scheuermann-Freestone, M.; Taylor, R.; Gunaruwan, P.; Williams, L.; Ashrafian, H.; Horowitz, J.; Fraser A.G.; Clarke, K.; et al. Metabolic modulation with perhexiline in chronic heart failure: A randomized, controlled trial of short-term use of a novel treatment. Circulation 2005, 112, 3280-3288. [CrossRef] [PubMed]

193. Holubarsch, C.J.; Rohrbach, M.; Karrasch, M.; Boehm, E.; Polonski, L.; Ponikowski, P.; Rhein, S. A double-blind randomized multicentre clinical trial to evaluate the efficacy and safety of two doses of etomoxir in comparison with placebo in patients with moderate congestive heart failure: The ERGO (Etomoxir for the Recovery of Glucose Oxidation) study. Clin. Sci. 2007, 113, 205-212. [CrossRef]

194. Abozguia, K.; Elliott, P.; McKenna, W.; Phan, T.T.; Nallur-Shivu, G.; Ahmed, I.; Maher, A.R.; Kaur, K.; Taylor, J.; Henning, A.; et al. Metabolic modulator perhexiline corrects energy deficiency and improves exercise capacity in symptomatic hypertrophic cardiomyopathy. Circulation 2010, 122, 1562-1569. [CrossRef]

195. Fragasso, G.; Palloshi, A.; Puccetti, P.; Silipigni, C.; Rossodivita, A.; Pala, M.; Calori, G.; Alfieri, O.; Margonato, A. A randomized clinical trial of trimetazidine, a partial free fatty acid oxidation inhibitor, in patients with heart failure. J. Am. Coll. Cardiol. 2006, 48, 992-998. [CrossRef]

196. Tuunanen, H.; Engblom, E.; Naum, A.; Nagren, K.; Scheinin, M.; Hesse, B.; Juhani Airaksinen, K.E.; Nuutila, P.; Iozzo, P.; Ukkonen, H.; et al. Trimetazidine, a metabolic modulator, has cardiac and extracardiac benefits in idiopathic dilated cardiomyopathy. Circulation 2008, 118, 1250-1258. [CrossRef]

197. Gao, D.; Ning, N.; Niu, X.; Hao, G.; Meng, Z. Trimetazidine: A meta-analysis of randomized controlled trials in heart failure. Heart 2011, 97, 278-286. [CrossRef] [PubMed]

198. El Alaoui-Talibi, Z.; Landormy, S.; Loireau, A.; Moravec, J. Fatty acid oxidation and mechanical performance of volume-overloaded rat hearts. Am. J. Physiol. 1992, 262, H1068-H1074. [CrossRef] [PubMed] 
199. El Alaoui-Talibi, Z.; Moravec, J. Carnitine transport and exogenous palmitate oxidation in chronically volume-overloaded rat hearts. Biochim. Biophys. Acta 1989, 1003, 109-114. [CrossRef]

200. Ruiz, M.; Labarthe, F.; Fortier, A.; Bouchard, B.; Legault Thompson, J.; Bolduc, V.; Rigal, O.; Chen, J.; Ducharme, A.; Crawford, P.A.; et al. Circulating acylcarnitine profile in human heart failure: A surrogate of fatty acid metabolic dysregulation in mitochondria and beyond. Am. J. Physiol. Heart Circ. Physiol. 2017, 313, H768-H781. [CrossRef] [PubMed]

201. Zhou, Q.Y.; Quaife, C.J.; Palmiter, R.D. Targeted disruption of the tyrosine hydroxylase gene reveals that catecholamines are required for mouse fetal development. Nature 1995, 374, 640-643. [CrossRef]

202. Baker, C.N.; Gidus, S.A.; Price, G.F.; Peoples, J.N.; Ebert, S.N. Impaired cardiac energy metabolism in embryos lacking adrenergic stimulation. Am. J. Physiol. Endocrinol. Metab. 2015, 308, E402-E413. [CrossRef]

203. Bao, X.; Lu, C.M.; Liu, F.; Gu, Y.; Dalton, N.D.; Zhu, B.Q.; Foster, E.; Chen, J.; Karliner, J.S.; Ross, J.; et al. Epinephrine is required for normal cardiovascular responses to stress in the phenylethanolamine N-methyltransferase knockout mouse. Circulation 2007, 116, 1024-1031. [CrossRef]

204. Ebert, S.N.; Rong, Q.; Boe, S.; Pfeifer, K. Catecholamine-synthesizing cells in the embryonic mouse heart. Ann. N. Y. Acad. Sci. 2008, 1148, 317-324. [CrossRef]

205. Goutis, A.; Felts, J.M. Effects of epinephrine, norepinephrine, glucose and insulin on extraction and oxidation of free fatty acid by myocardium. Circulation 1963, 28, 729.

206. Gold, M.; Atlas, H.J.; Scott, J.C.; Spitzen, J.J. Effect of norepinephrine on myocardial free fatty acid uptake and oxidation. Proc. Sot. Exp. Biol. Med. 1965, 118, 876-879. [CrossRef]

207. Crass, M.F., III; Shipp, J.C.; Pieper, G.M. Effects of catecholamines on myocardial endogenous substrates and contractility. Am. J. Physiol. 1975, 228, 618-627. [CrossRef]

208. Murthy, V.K.; Bauman, M.D.; Shipp, J.C. Effects of epinephrine and perfusion pressure on the peak aortic pressure development and glucose transport in the isolated perfused heart of normal and diabetic rats. Basic Res. Cardiol. 1983, 78, 281-288. [CrossRef]

209. Collins-Nakai, R.L.; Noseworthy, D.; Lopaschuk, G.D. Epinephrine increases ATP production in hearts by preferentially increasing glucose metabolism. Am. J. Physiol. Heart Circ. Physiol. 1994, 267, H1862-H1871. [CrossRef] [PubMed]

210. Robertson, R.P.; Porte, D., Jr. Adrenergic modulation of basal insulin secretion in man. Diabetes 1973, 22, 1-8. [CrossRef] [PubMed]

211. Lerner, R.L.; Porte, D., Jr. Epinephrine: Selective inhibition of the acute insulin response to glucose. J. Clin. Investig. 1971, 50, 2453-2457. [CrossRef] [PubMed]

212. Christensen, N.J.; Videbaek, J. Plasma catecholamines and carbohydrate metabolism in patients with acute myocardial infarction. J. Clin. Investig. 1974, 54, 278-286. [CrossRef] [PubMed]

213. Hue, L.; Feliu, J.E.; Hers, H.G. Control of gluconeogenesis and of enzymes of glycogen metabolism in isolated rat hepatocytes. A parallel study of the effect of phenylephrine and of glucagon. Biochem. J. 1978, 176, 791-797. [CrossRef] [PubMed]

214. García-Sáinz, J.A.; Hernández-Sotomayor, S.M. Adrenergic regulation of gluconeogenesis: Possible involvement of two mechanisms of signal transduction in $\alpha_{1}$-adrenergic action. PNAS 1985, 82, 6727-6730. [CrossRef] [PubMed]

215. Stark, B.; Keller, U. a 1 -adrenergic stimulation of ketogenesis and fatty acid oxidation is associate with inhibition of lipogenesis in rat hepatocytes. Experientia 1987, 43, 1104-1106. [CrossRef]

216. Chan, T.M.; Exton, J.H. Studies on $\alpha$-adrenergic activation of hepatic glucose output. Studies on $\alpha$-adrenergic inhibition of hepatic pyruvate kinase and activation of gluconeogenesis. J. Biol. Chem. 1978, 253, 6393-6400. [CrossRef]

217. De Oliveira, A.L.; de Paula, M.N.; Comar, J.F.; Vilela, V.R.; Peralta, R.M.; Bracht, A. Adrenergic metabolic and hemodynamic effects of octopamine in the liver. Int. J. Mol. Sci. 2013, 14, 21858-21872. [CrossRef] [PubMed]

218. Dileepan, K.N.; Khawaja, A.M.; Wagle, S.R. Studies on the mechanism of action of somatostatin on renal gluconeogenesis: Evidence for the involvement of $\alpha_{1}$-adrenergic stimuli. Arch. Biochem. Biophys. 1982, 213, 169-176. [CrossRef]

219. Dileepan, K.N.; Wagle, S.R. Somatostatin: A metabolic regulator. Life Sci. 1985, 37, 2335-2343. [CrossRef]

220. Hutson, N.J.; Brumley, F.T.; Assimacopoulos, F.D.; Harper, S.C.; Exton, J.H. Studies on the $\alpha$-adrenergic activation of hepatic glucose output. I. Studies on the $\alpha$-adrenergic activation of phosphorylase and gluconeogenesis and inactivation of glycogen synthase in isolated rat liver parenchymal cells. J. Biol. Chem. 1976, 251, 5200-5208. [CrossRef]

221. Assimacopoulos-Jeannet, F.D.; Blackmore, P.F.; Exton, J.H. Studies on $\alpha$-adrenergic activation of hepatic glucose output. Studies on role of calcium in $\alpha$-adrenergic activation of phosphorylase. J. Biol. Chem. 1977, 252, 2662-2669. [CrossRef]

222. Packer, M. Lessons learned from the DAPA-HF trial concerning the mechanisms of benefit of SGLT2 inhibitors on heart failure events in the context of other large-scale trials nearing completion. Cardiovasc. Diabetol. 2019, 18, 129. [CrossRef]

223. McMurray, J.J.V.; Solomon, S.D.; Docherty, K.F.; Jhund, P.S. The dapagliflozin and prevention of adverse outcomes in heart failure trial (DAPA-HF) in context. Eur. Heart J. 2020, ii, ehz916. [CrossRef]

224. Swe, M.T.; Thongnak, L.; Jaikumkao, K.; Pongchaidecha, A.; Chatsudthipong, V.; Lungkaphin, A. Dapagliflozin not only improves hepatic injury and pancreatic endoplasmic reticulum stress, but also induces hepatic gluconeogenic enzymes expression in obese rats. Clin. Sci. 2019, 133, 2415-2430. [CrossRef]

225. Basu, R.; Shah, P.; Basu, A.; Norby, B.; Dicke, B.; Chandramouli, V.; Cohen, O.; Landau, B.R.; Rizza, R.A. Comparison of the effects of pioglitazone and metformin on hepatic and extra-hepatic insulin action in people with type 2 diabetes. Diabetes 2008, 57, 24-31. [CrossRef]

226. Madiraju, A.K.; Erion, D.M.; Rahimi, Y.; Zhang, X.M.; Braddock, D.T.; Albright, R.A. Metformin suppresses gluconeogenesis by inhibiting mitochondrial glycerophosphate dehydrogenase. Nature 2014, 510, 542-546. [CrossRef] 
227. Cahill, G.F., Jr.; Veech, R.L. Ketoacids? Good medicine? Trans. Am. Clin. Climatol. Assoc. 2003, 114, 149-163.

228. Abel, E.D.; O'Shea, K.M.; Ramasamy, R. Insulin resistance: Metabolic mechanisms and consequences in the heart. Arterioscler. Thromb. Vasc. Biol. 2012, 32, 2068-2076. [CrossRef] [PubMed]

229. Guo, H.; Callaway, J.B.; Ting, J.P. Inflammasomes: Mechanism of action, role in disease and therapeutics. Nat. Med. 2015, 21, 677-687. [CrossRef]

230. Puchalska, P.; Crawford, P.A. Multi-dimensional roles of ketone bodies in fuel metabolism, signaling, and therapeutics. Cell. Metab. 2017, 25, 262-284. [CrossRef]

231. Kim, S.R.; Lee, S.G.; Kim, S.H.; Kim, J.H.; Choi, E.; Cho, W.; Rim, J.H.; Hwang, I.; Lee, C.J.; Lee, M.; et al. SGLT2 inhibition modulates NLRP3 inflammasome activity via ketones and insulin in diabetes with cardiovascular disease. Nat. Commun. 2020, 11, 2127. [CrossRef] [PubMed]

232. Seto, E.; Yoshida, M. Erasers of histone acetylation: The histone deacetylase enzymes. Cold Spring Harb. Perspect. Biol. 2014, 6, a018713. [CrossRef] [PubMed]

233. Egert, S.; Nguyen, N.; Schwaiger, M. Contribution of $\alpha$-adrenergic and $\beta$-adrenergic stimulation to ischemia-induced glucose transporter (GLUT) 4 and GLUT1 translocation in the isolated perfused rat heart. Circ. Res. 1999, 84, 1407-1415. [CrossRef]

234. Doenst, T.; Taegtmeyer, H. $\alpha$-Adrenergic Stimulation Mediates Glucose Uptake Through Phosphatidylinositol 3-Kinase in Rat Heart. Circ. Res. 1999, 84, 467-474. [CrossRef]

235. Shi, T.; Papay, R.S.; Perez, D.M. The role of $\alpha_{1}$-adrenergic receptors in regulating metabolism: Increased glucose tolerance, leptin secretion and lipid oxidation. J. Recept. Signal. Transduct. Res. 2017, 37, 124-132. [CrossRef] [PubMed]

236. Sato, M.; Evans, B.A.; Sandström, A.L.; Chia, L.Y.; Mukaida, S.; Thai, B.S.; Nguyen, A.; Lim, L.; Tan, C.; Baltos, J.A.; et al. $\alpha_{1 \mathrm{~A}}$-Adrenoceptors activate mTOR signalling and glucose uptake in cardiomyocytes. Biochem. Pharmacol. 2018, 148, 27-40. [CrossRef] [PubMed]

237. Papay, R.S.; Perez, D.M. $\alpha_{1}$-Adrenergic receptors increase glucose oxidation under normal and ischemic conditions in adult mouse cardiomyocytes. J. Recept. Signal. Transduct. Res. 2021, 41, 138-144. [CrossRef] [PubMed]

238. Liu, I.M.; Tsai, C.C.; Lai, T.Y.; Cheng, J.T. Stimulatory effect of isoferulic acid on $\alpha_{1 \mathrm{~A}}$-adrenoceptor to increase glucose uptake into cultured myoblast C2C12 cells of mice. Auton. Neurosci. 2001, 88, 175-180. [CrossRef]

239. Hutchinson, D.S.; Bengtsson, T. $\alpha_{1 \mathrm{~A}}$-adrenoceptors activate glucose Uptake in L6 muscle cells through a phospholipase C-, phosphatidylinositol-3 kinase-, andatypical protein kinase C-dependent pathway. Endocrinology 2005, 146, 901-912. [CrossRef] [PubMed]

240. Hutchinson, D.S.; Bengtsson, T. AMP-activated protein kinase activation by adrenoceptors in L6 skeletal muscle cells: Mediation by $\alpha_{1}$-adrenoceptors causing glucose uptake. Diabetes 2006, 55, 682-690. [CrossRef]

241. Faintrenie, G.; Géloën, A. $\alpha_{1}$-adrenergic stimulation of glucose uptake in rat white adipocytes. J. Pharmacol. Exp. Ther. 1998, 1286, 607-610.

242. Cheng, J.-T.; Liu, I.-M.; Yen, S.-T.; Chen, P.-C. Role of $\alpha_{1 \mathrm{~A}}$-adrenoceptor in the regulation of glucose uptake into white adipocyte of rats in vitro. Auton. Neurosci. 2000, 84, 140-146. [CrossRef]

243. Boschmann, M.; Krupp, G.; Luft, F.C.; Klaus, S.; Jordan, J. In vivo response to $\alpha_{1}$-adrenoreceptor stimulation in human white adipose tissue. Obes. Res. 2002, 10, 555-558. [CrossRef]

244. Flechtner-Mors, M.; Jenkinson, C.P.; Alt, A.; Adler, G.; Ditschuneit, H.H. In vivo $\alpha_{1}$-adrenergic lipolytic activity in subcutaneous adipose tissue of obese subjects. J. Pharmacol. Exp. Ther. 2002, 301, 229-233. [CrossRef] [PubMed]

245. Flechtner-Mors, M.; Jenkinson, C.P.; Alt, A.; Biesalski, H.K.; Adler, G.; Ditschuneit, H.H. Sympathetic regulation of glucose uptake by the $\alpha_{1}$-adrenoceptor in human obesity. Obes. Res. 2004, 12, 612-620. [CrossRef]

246. Shi, T.; Papay, R.S.; Perez, D.M. $\alpha_{1 \mathrm{~A}}$-Adrenergic receptor prevents cardiac ischemic damage through PKC $\delta / G L U T 1 / 4-m e d i a t e d$ glucose uptake. J. Recept. Signal. Transduct. Res. 2016, 36, 261-270. [CrossRef] [PubMed]

247. Cavalli, A.; Lattion, A.L.; Hummler, E.; Nenniger, M.; Pedrazzini, T.; Aubert, J.F.; Michel, M.C.; Yang, M.; Lembo, G.; Vecchione, C.; et al. Decreased blood pressure response in mice deficient of the $\alpha_{1 \mathrm{~b}}$-adrenergic receptor. Proc. Natl. Acad. Sci. USA 1997, 94, 11589-115894. [CrossRef]

248. Zuscik, M.J.; Sand, S.; Ross, S.A.; Waugh, D.J.J.; Gaivin, R.J.; Morilak, D.; Perez, D.M. Overexpression of the $\alpha_{1 b}-$ Adrenergic receptor causes apoptotic neurodegeneration: A multiple system atrophy. Nat. Med. 2000, 6, 1388-1394. [CrossRef]

249. Zuscik, M.J.; Chalothorn, D.; Hellard, D.; Deighan, C.; McGee, A.; Daly, C.; Waugh, D.J.; Ross, S.A.; Gaivin, R.J.; Morehead, A.J.; et al. Hypotension, autonomic failure and cardiac hypertrophy in transgenic mice over-expressing the $\alpha_{1 b}$-adrenergic receptor. J. Biol. Chem. 2001, 276, 13738-13743. [CrossRef] [PubMed]

250. Angeloni, C.; Maraldi, T.; Ghelli, A.; Rugolo, M.; Leoncini, E.; Hakim, G.; Hrelia, S. Green tea modulates $\alpha_{1}$-adrenergic stimulated glucose transport in cultured rat cardiomyocytes. J. Agric. Food Chem. 2007, 55, 7553-7558. [CrossRef] [PubMed]

251. Rorabaugh, B.R.; Gaivin, R.J.; Papay, R.S.; Shi, T.; Simpson, P.C.; Perez, D.M. Both $\alpha_{1 \mathrm{~A}}$ - and $\alpha_{1 \mathrm{~B}}$-Adrenergic Receptors Cross-talk to Downregulate $\beta_{1}$-ARs in Mouse Heart: Coupling to Differential PTX-Sensitive Pathways. J. Mol. Cell. Cardiol. 2005, 39, 777-784. [CrossRef]

252. Nishino, Y.; Miura, T.; Miki, T.; Sakamoto, J.; Nakamura, Y.; Ikeda, Y.; Kobayashi, H.; Shimamoto, K. Ischemic preconditioning activates AMPK in a PKC-dependent manner and induces GLUT4 up-regulation in the late phase of cardioprotection. Cardiovasc. Res. 2004, 61, 610-619. [CrossRef] 
253. Gundewar, S.; Calvert, J.W.; Jha, S.; Toedt-Pingel, I.; Ji, S.Y.; Nunez, D.; Ramachandran, A.; Anaya-Cisneros, M.; Tian, R.; Lefer, D.J. Activation of AMP-activated protein kinase by metformin improves left ventricular function and survival in heart failure. Circ. Res. 2009, 104, 403-411. [CrossRef]

254. Turrell, H.E.; Rodrigo, G.C.; Norman, R.I.; Dickens, M.; Standen, N.B. Phenylephrine preconditioning involves modulation of cardiac sarcolemmal K(ATP) current by PKC delta, AMPK and p38 MAPK. J. Mol. Cell. Cardiol. 2011, 51, 370-380. [CrossRef] [PubMed]

255. Zarrinpashneh, E.; Beauloye, C.; Ginion, A.; Pouleur, A.C.; Havaux, X.; Hue, L.; Viollet, B.; Vanoverschelde, J.L.; Bertrand, L. AMPK $\alpha 2$ counteracts the development of cardiac hypertrophy induced by isoproterenol. Biochem. Biophys. Res. Commun. 2008, 376, 677-681. [CrossRef] [PubMed]

256. Xiao, H.; Ma, X.; Feng, W.; Fu, Y.; Lu, Z.; Xu, M.; Shen, Q.; Zhu, Y.; Zhang, Y. Metformin attenuates cardiac fibrosis by inhibiting the TGFb1-Smad3 signalling pathway. Cardiovasc. Res. 2010, 87, 504-513. [CrossRef]

257. Gaskin, F.S.; Kamada, K.; Zuidema, M.Y.; Jones, A.W.; Rubin, L.J.; Korthuis, R.J. Isoform-selective 5'-AMP-activated protein kinase-dependent preconditioning mechanisms to prevent postischemic leukocyte-endothelial cell adhesive interactions. Am. J. Physiol. Heart Circ. Physiol. 2011, 300, H1352-H1360. [CrossRef]

258. Cieslik, K.A.; Taffet, G.E.; Crawford, J.R.; Trial, J.; Mejia Osuna, P.; Entman, M.L. AICAR-dependent AMPK activation improves scar formation in the aged heart in a murine model of reperfused myocardial infarction. J. Mol. Cell. Cardiol. 2013, 63, 26-36. [CrossRef] [PubMed]

259. Ma, X.; Fu, Y.; Xiao, H.; Song, Y.; Chen, R.; Shen, J.; An, X.; Shen, Q.; Li, Z.; Zhang, Y. Cardiac Fibrosis Alleviated by Exercise Training Is AMPK-Dependent. PLoS ONE 2015, 10, e0129971. [CrossRef]

260. Han, X.; Tai, H.; Wang, X.; Wang, Z.; Zhou, J.; Wei, X.; Ding, Y.; Gong, H.; Mo, C.; Zhang, J.; et al. AMPK activation protects cells from oxidative stress-induced senescence via autophagic flux restoration and intracellular NAD(+) elevation. Aging Cell. 2016, 15, 416-427. [CrossRef]

261. Garg, G.; Singh, S.; Singh, A.K.; Rizvi, S.I. Metformin Alleviates Altered Erythrocyte Redox Status During Aging in Rats. Rejuvenation Res. 2017, 20, 15-24. [CrossRef] [PubMed]

262. Na, H.J.; Park, J.S.; Pyo, J.H.; Jeon, H.J.; Kim, Y.S.; Arking, R.; Yoo, M.-A. Metformin inhibits age-related centrosome amplification in Drosophila midgut stem cells through AKT/TOR pathway. Mech. Ageing Dev. 2015, 149, 8-18. [CrossRef] [PubMed]

263. Marsin, A.S.; Bertrand, L.; Rider, M.H.; Deprez, J.; Beauloye, C.; Vincent, M.F.; Van den Berghe, G.; Carling, D.; Hue, L. Phosphorylation and activation of heart PFK-2 by AMPK has a role in the stimulation of glycolysis during ischaemia. Curr. Biol. 2000, 10, 1247-1255. [CrossRef]

264. Russell, R.R., 3rd; Li, J.; Coven, D.L.; Pypaert, M.; Zechner, C.; Palmeri, M.; Giordano, F.J.; Mu, J.; Birnbaum, M.J.; Young, L.H. AMP-activated protein kinase mediates ischemic glucose uptake and prevents postischemic cardiac dysfunction, apoptosis, and injury. J. Clin. Investig. 2004, 114, 495-503. [CrossRef]

265. Xu, M.; Zhao, Y.T.; Song, Y.; Hao, T.P.; Lu, Z.Z.; Han, Q.D.; Wang, S.Q.; Zhang, Y.Y. $\alpha_{1}$-adrenergic receptors activate AMP-activated protein kinase in rat hearts. Sheng Li Xue Bao 2007, 59, 175-182. [PubMed]

266. Pang, T.; Rajapurohitam, V.; Cook, M.A.; Karmazyn, M. Differential AMPK phosphorylation sites associated with phenylephrine vs. antihypertrophic effects of adenosine agonists in neonatal rat ventricular myocytes. Am. J. Physiol. Heart Circ. Physiol. 2010, 298, H1382-H1390. [CrossRef]

267. Horie, T.; Ono, K.; Nagao, K.; Nishi, H.; Kinoshita, M.; Kawamura, T.; Wada, H.; Shimatsu, A.; Kita, T.; Hasegawa, K. Oxidative stress induces GLUT4 translocation by activation of PI3-K/Akt and dual AMPK kinase in cardiac myocytes. J. Cell. Physiol. 2008, 215, 733-742. [CrossRef] [PubMed]

268. Miyamoto, L.; Ebihara, K.; Kusakabe, T.; Aotani, D.; Yamamoto-Kataoka, S.; Sakai, T.; Aizawa-Abe, M.; Yamamoto, Y.; Fujikura, J.; Hayashi, T.; et al. Leptin activates hepatic 5'-AMP-activated protein kinase through sympathetic nervous system and $\alpha_{1}$ adrenergic receptor: A potential mechanism for improvement of fatty liver in lipodystrophy by leptin. J. Biol. Chem. 2012, 287, 40441-40447. [CrossRef]

269. Pulinilkunnil, T.; He, H.; Kong, D.; Asakura, K.; Peroni, O.D.; Lee, A.; Kahn, B.B. Adrenergic regulation of AMP-activated protein kinase in brown adipose tissue in vivo. J. Biol. Chem. 2011, 286, 8798-8809. [CrossRef] [PubMed]

270. Minokoshi, Y.; Kim, Y.B.; Peroni, O.D.; Fryer, L.G.; Müller, C.; Carling, D.; Kahn, B.B. Leptin stimulates fatty-acid oxidation by activating AMP-activated protein kinase. Nature 2002, 415, 339-343. [CrossRef]

271. Kishi, K.; Yuasa, T.; Minami, A.; Yamada, M.; Hagi, A.; Hayashi, H.; Kemp, B.E.; Witters, L.A.; Ebina, Y. AMP-activated protein kinase is activated by the stimulations of G(q)-coupled receptors. Biochem. Biophys. Res. Commun. 2000, 276, 16-22. [CrossRef]

272. Glund, S.; Deshmukh, A.; Long, Y.C.; Moller, T.; Koistinen, H.A.; Caidahl, K.; Zierath, Z.; Krook, A. Interleukin-6 directly increases glucose metabolism in resting human skeletal muscle. Diabetes 2007, 56, 1630-1637. [CrossRef]

273. Cadaret, C.N.; Beede, K.A.; Riley, H.E.; Yates, D.T. Acute exposure of primary rat soleus muscle to zilpaterol $\mathrm{HCl}\left(\beta_{2}\right.$ adrenergic agonist), TNF $\alpha$, or IL- 6 in culture increases glucose oxidation rates independent of the impact on insulin signaling or glucose uptake. Cytokine 2017, 96, 107-113. [CrossRef]

274. Karwi, Q.G.; Uddin, G.M.; Ho, K.L.; Lopaschuk, G.D. Loss of Metabolic Flexibility in the Failing Heart. Front. Cardiovasc. Med. 2018, 5, 68. [CrossRef]

275. Xiao, X.; Su, G.; Brown, S.N.; Chen, L.; Ren, J.; Zhao, P. Peroxisome proliferator-activated receptors gamma and alpha agonists stimulate cardiac glucose uptake via activation of AMP-activated protein kinase. J. Nutr. Biochem. 2010, 21, 621-626. [CrossRef] 
276. Huang, Q.; Huang, J.; Zeng, Z.; Luo, J.; Liu, P.; Chen, S.; Liu, B.; Pan, X.; Zang, L.; Zhou, S. Effects of ERK1/2/PPAR $\alpha / S C A D$ signal pathways on cardiomyocyte hypertrophy induced by insulin-like growth factor 1 and phenylephrine. Life Sci. 2015, 124, 41-49. [CrossRef] [PubMed]

277. Kar, D.; Bandyopadhyay, A. Targeting Peroxisome Proliferator Activated Receptor $\alpha$ (PPAR $\alpha)$ for the Prevention of Mitochondrial Impairment and Hypertrophy in Cardiomyocytes. Cell. Physiol. Biochem. 2018, 49, 245-259. [CrossRef] [PubMed]

278. Liu, Z.; Hua, J.; Cai, W.; Zhan, Q.; Lai, W.; Zeng, Q.; Ren, H.; Xu, D. N-terminal truncated peroxisome proliferator-activated receptor- $\gamma$ coactivator- $1 \alpha$ alleviates phenylephrine-induced mitochondrial dysfunction and decreases lipid droplet accumulation in neonatal rat cardiomyocytes. Mol. Med. Rep. 2018, 18, 2142-2152. [CrossRef]

279. Lee, Y.-J.; Kim, H.S.; Seo, H.S.; Na, J.O.; Jang, Y.-N.; Han, Y.-M.; Kim, H.-M. Stimulation of $\alpha_{1}$-Adrenergic Receptor Ameliorates Cellular Functions of Multiorgans beyond Vasomotion through PPAR $\delta$. PPAR Res. 2020, 3785137. [CrossRef]

280. Barger, P.M.; Kelly, D.P. PPAR signaling in the control of cardiac energy metabolism. Trends. Cardiovasc. Med. 2000, 10, 238-245. [CrossRef]

281. Huss, J.M.; Kelly, D.P. Mitochondrial energy metabolism in heart failure: A question of balance. J. Clin. Investig. 2005, 115, 547-555. [CrossRef] [PubMed]

282. Burkart, E.M.; Sambandam, N.; Han, X.; Gross, R.W.; Courtois, M.; Gierasch, C.M.; Shoghi, K.; Welch, M.J.; Kelly, D.P. Nuclear receptors PPAR $\beta / \delta$ and PPAR $\alpha$ direct distinct metabolic regulatory programs in the mouse heart. J. Clin. Investig. 2007, 117, 3930-3939. [CrossRef]

283. Yang, Q.; Long, Q. PPARd, a Potential Therapeutic Target for Heart Disease. Nucl. Recept. Res. 2018, 5, 101375. [CrossRef] [PubMed]

284. Cheng, L.; Ding, G.; Qin, Q.; Huang, Y.; Lewis, W.; He, N.; Evans, R.M.; Schneider, M.D.; Brako, F.A.; Xiao, Y.; et al. Cardiomyocyterestricted peroxisome proliferator-activated receptor- $\delta$ deletion perturbs myocardial fatty acid oxidation and leads to cardiomyopathy. Nat. Med. 2004, 10, 1245-1250. [CrossRef]

285. Li, P.; Luo, S.; Pan, C.; Cheng, X. Modulation of fatty acid metabolism is involved in the alleviation of isoproterenol-induced rat heart failure by fenofibrate. Mol. Med. Rep. 2015, 12, 7899-7906. [CrossRef]

286. Yuan, J.; Wu, J.; Han, Z.G. Fenofibrate improves energy metabolism and attenuates isoproterenol induced acute myocardial ischemic injury in rats via PPAR $\alpha$ activation. Zhonghua Xin Xue Guan Bing Za Zhi 2008, 36, 847-850.

287. Zuo, X.; Peng, Z.; Moussalli, M.J.; Morris, J.S.; Broaddus, R.R.; Fischer, S.M.; Shureiqi, I. Targeted genetic disruption of peroxisome proliferator-activated receptor-delta and colonic tumorigenesis. J. Natl. Cancer Inst. 2009, 101, 762-767. [CrossRef]

288. Zuo, X.; Xu, M.; Yu, J.; Wu, Y.; Moussalli, M.J.; Manyam, G.C.; Lee, S.I.; Lee, S.I.; Liang, S.; Gagea, M.; et al. Potentiation of colon cancer susceptibility in mice by colonic epithelial PPAR- $\delta / \beta$ overexpression. J. Natl. Cancer Inst. 2014, 106, dju052. [CrossRef]

289. Xi, Y.; Zhang, Y.; Zhu, S.; Luo, Y.; Xu, P.; Huang, Z. PPAR-Mediated Toxicology and Applied Pharmacology. Cells 2020, 9 , 352. [CrossRef]

290. Wagner, N.; Wagner, K.D. PPAR Beta/Delta and the Hallmarks of Cancer. Cells 2020, 9, 1133. [CrossRef]

291. Konstandi, M.; Kypreos, K.E.; Matsubara, T.; Xepapadaki, E.; Shah, Y.M.; Krausz, K.; Andriopoulou, C.E.; Kofinas, A.; Gonzalez, F.J. Adrenoceptor-related decrease in serum triglycerides is independent of PPAR $\alpha$ activation. FEBS J. 2019, 286, 4328-4341. [CrossRef] [PubMed]

292. Willis, M.S.; Ilaiwy, A.; Montgomery, M.D.; Simpson, P.C.; Jensen, B.C. The $\alpha_{1 \mathrm{~A}}$-adrenergic receptor agonist A61603 reduces cardiac polyunsaturated fatty acid and endocannabinoid metabolites associated with inflammation in vivo. Metabolomics 2016, 12, 155. [CrossRef] [PubMed]

293. Burcelin, R.; Uldry, M.; Foretz, M.; Perrin, C.; Dacosta, A.; Nenniger-Tosato, M.; Seydoux, J.; Cotecchia, S.; Thorens, B. Impaired glucose homeostasis in mice lacking the $\alpha_{1 b}$-adrenergic receptor subtype. J. Biol. Chem. 2004, 279, 1108-1115. [CrossRef]

294. Zimmer, H.G.; Ibel, H.; Suchner, U. $\beta$-adrenergic agonists stimulate the oxidative pentose phosphate pathway in the rat heart. Circ. Res. 1990, 67, 1525-1534. [CrossRef]

295. Zimmer, H.G.; Lankat-Buttgereit, B.; Kolbeck-Rühmkorff, C.; Nagano, T.; Zierhut, W. Effects of norepinephrine on the oxidative pentose phosphate pathway in the rat heart. Circ. Res. 1992, 71, 451-459. [CrossRef] [PubMed]

296. Zimmer, H.G.; Irlbeck, M.; Kolbeck-Rühmkorff, C.K. Response of the rat heart to catecholamines and thyroid hormones. Mol. Cell. Biochem. 1995, 147, 105-114. [CrossRef] [PubMed]

297. Irlbeck, M.; Zimmer, H.G. The functional and metabolic responses of the heart to catecholamines are attenuated in diabetic rats. Cardioscience 1995, 6, 131-138. [PubMed]

298. Giannattasio, C.; Cattaneo, B.M.; Seravalle, G.; Carugo, S.; Mangoni, A.A.; Grassi, G.; Zanchetti, A.; Mancia, G. $\alpha_{1}$-blocking properties of carvedilol during acute and chronic administration. J. Cardiovasc. Pharmacol. 1992, 19, S18-S22. [CrossRef] [PubMed]

299. Nagano, T.; O'Harrow, S.; Sponer, G.; Zimmer, H.G. Norepinephrine-induced changes in rat heart function, metabolism, and weight are antagonized by carvedilol. J. Cardiovasc. Pharmacol. 1993, 21, 530-536. [CrossRef] [PubMed]

300. Woo, S.H.; Lee, C.O. Role of PKC in the effects of $\alpha_{1}$-adrenergic stimulation on $\mathrm{Ca}^{2+}$ transients, contraction and Ca ${ }^{2+}$ current in guinea-pig ventricular myocytes. Pflugers. Arch. 1999, 437, 335-344. [CrossRef] [PubMed]

301. Wier, W.G.; Morgan, K.G. $\alpha_{1}$-adrenergic signaling mechanisms in contraction of resistance arteries. Rev. Physiol. Biochem. Pharmacol. 2003, 150, 91-139. 
302. Villalba, N.; Stankevicius, E.; Garcia-Sacristán, A.; Simonsen, U.; Prieto, D. Contribution of both $\mathrm{Ca}^{2+}$ entry and Ca ${ }^{2+}$ sensitization to the $\alpha_{1}$-adrenergic vasoconstriction of rat penile small arteries. Am. J. Physiol. Heart Circ. Physiol. 2007, 292, H1157-H1169. [CrossRef]

303. Gutiérrez, A.; Contreras, C.; Sánchez, A.; Prieto, D. Role of Phosphatidylinositol 3-Kinase (PI3K), Mitogen-Activated Protein Kinase (MAPK), and Protein Kinase C (PKC) in Calcium Signaling Pathways Linked to the $\alpha_{1}$-Adrenoceptor in Resistance Arteries. Front. Physiol. 2019, 10, 55. [CrossRef] [PubMed]

304. Fordyce, C.B.; Roe, M.T.; Ahmad, T.; Libby, P.; Borer, J.S.; Hiatt, W.R.; Bristow, M.R.; Packer, M.; Wasserman, S.M.; Braunstein, N.; et al. Cardiovascular drug development: Is it dead or just hibernating? J. Am. Coll. Cardiol. 2015, 65, 1567-1582. [CrossRef] [PubMed]

305. Ruffolo, R.R., Jr.; Rice, P.J.; Patil, P.N.; Hamada, A.; Miller, D.D. Differences in the applicability of the Easson-Stedman hypothesis to the $\alpha_{1}$ - and $\alpha_{2}$-adrenergic effects of phenethylamines and imidazolines. Eur. J. Pharmacol. 1983, 86, 471-475. [CrossRef]

306. Ruffolo, R.R., Jr.; Waddell, J.E. Receptor interactions of imidazolines. IX. Cirazoline is an $\alpha_{1}$-adrenergic agonist and an $\alpha_{2}-$ adrenergic antagonist. J. Pharmacol. Exp. Ther. 1982, 222, 29-36. [PubMed]

307. Hieble, J.P.; DeMarinis, R.M.; Matthews, W.D. Evidence for and against heterogeneity of $\alpha_{1}$-adrenoceptors. Life Sci. 1986, 38, 1339-1350. [CrossRef]

308. Ruffolo, R.R., Jr.; Yaden, E.L.; Waddell, J.E.; Dillard, R.D. Receptor interactions of imidazolines. VI. Significance of carbon bridge separating phenyl and imidazoline rings of tolazoline-like $\alpha$-adrenergic imidazolines. J. Pharmacol. Exp. Ther. 1980, 214, 535-540. [PubMed]

309. Knepper, S.M.; Buckner, S.A.; Brune, M.E.; DeBernardis, J.F.; Meyer, M.D.; Hancock, A.A. A-61603, a potent $\alpha_{1}$-adrenergic receptor agonist, selective for the $\alpha_{1 \mathrm{~A}}$ receptor subtype. J. Pharmacol. Exp. Ther. 1995, 274, 97-103.

310. Minneman, K.P.; Theroux, T.L.; Hollinger, S.; Han, C.; Esbenshade, T.A. Selectivity of agonists for cloned $\alpha_{1}$-adrenergic receptor subtypes. Mol. Pharmacol. 1994, 46, 929-936.

311. Waugh, D.J.J.; Gaivin, R.J.; Zuscik, M.J.; Gonzalez-Cabrera, P.; Ross, S.A.; Yun, J.; Perez, D.M. Phe308 and Phe312 in TM VII are major sites of $\alpha_{1}$-Adrenergic Receptor Antagonist Binding: Imidazoline Agonists Bind Like Antagonists. J. Biol. Chem. 2001, 276, 25366-25371. [CrossRef]

312. Musselman, D.M.; Ford, A.P.; Gennevois, D.J.; Harbison, M.L.; Laurent, A.L.; Mokatrin, A.S.; Stoltz, R.R.; Blue, D.R. A randomized crossover study to evaluate Ro 115-1240, a selective $\alpha_{1 \mathrm{~A} / \mathrm{L}}$-adrenoceptor partial agonist in women with stress urinary incontinence. BJU Int. 2004, 93, 78-83. [CrossRef]

313. Blue, D.R.; Daniels, D.V.; Gever, J.R.; Jett, M.F.; O'Yang, C.; Tang, H.M.; Williams, T.J.; Ford, A.P. Pharmacological characteristics of Ro 115-1240, a selective $\alpha_{1 \mathrm{~A} / \mathrm{L}}$-adrenoceptor partial agonist: A potential therapy for stress urinary incontinence. BJU Int. 2004, 93, 162-170. [CrossRef] [PubMed]

314. Evans, B.A.; Broxton, N.; Merlin, J.; Sato, M.; Hutchinson, D.S.; Christopoulos, A.; Summers, R.J. Quantification of functional selectivity at the human $\alpha_{1 \mathrm{~A}}$-adrenoceptor. Mol. Pharmacol. 2011, 79, 298-307. [CrossRef]

315. Da Silva, E.D.; Sato, M.; Merlin, J.; Broxton, N.; Hutchinson, D.S.; Ventura, S.; Evans, B.A.; Summers, R.J. Factors influencing biased agonism in recombinant cells expressing the human $\alpha_{1 \mathrm{~A}}$-adrenoceptor. Br. J. Pharmacol. 2017, 174, 2318-2333. [CrossRef] [PubMed]

316. Bishop, M.J. Recent Advances in the Discovery of $\alpha_{1}$-Adrenoceptor Agonists. Curr. Top. Med. Chem. 2007, 7, 135-145. [CrossRef] [PubMed]

317. Christopoulos, A. Allosteric binding sites on cell-surface receptors: Novel targets for drug discovery. Nat. Rev. Drug Discov. 2002, 1, 198-210. [CrossRef] [PubMed]

318. Maeda, K.; Das, D.; Nakata, H.; Mitsuya, H. CCR5 inhibitors: Emergence, success, and challenges. Expert Opin. Emerg. Drugs. 2012, 17, 135-145. [CrossRef] [PubMed]

319. Wold, E.A.; Chen, J.; Cunningham, K.A.; Zhou, J. Allosteric Modulation of Class A GPCRs: Targets, Agents, and Emerging Concepts. J. Med. Chem. 2019, 62, 88-127. [CrossRef] [PubMed]

320. Perez, D.M. Novel Positive Allosteric Modulators of the $\alpha_{1 \mathrm{~A}}$-Adrenergic Receptor to Treat Alzheimer's Disease. Brain Connect. 2021, 11, A1-A8.

321. Kuschel, M.; Zhou, Y.Y.; Spurgeon, H.A.; Bartel, S.; Karczewski, P.; Zhang, S.J.; Krause, E.G.; Lakatta, E.G.; Xiao, R.P. $\beta_{2}$-Adrenergic cAMP signaling is uncoupled from phosphorylation of cytoplasmic proteins in canine heart. Circulation 1999, 99, $2458-2465$. [CrossRef]

322. McConville, P.; Fishbein, K.W.; Lakatta, E.G.; Spencer, R.G. Differences in the bioenergetic response of the isolated perfused rat heart to selective $\beta_{1}$ - and $\beta_{2}$-adrenergic receptor stimulation. Circulation 2003, 107, 2146-2152. [CrossRef]

323. Goodwin, G.W.; Ahmad, F.; Taegtmeyer, H. Preferential oxidation of glycogen in isolated working rat heart. J. Clin. Investig. 1996, 97, 1409-1416. [CrossRef]

324. Goodwin, G.W.; Ahmad, F.; Doenst, T.; Taegtmeyer, H. Energy provision from glycogen, glucose, and fatty acids on adrenergic stimulation of isolated working rat hearts. Am. J. Physiol. 1998, 274, H1239-H1247. [CrossRef] [PubMed]

325. Nevzorova, J.; Bengtsson, T.; Evans, B.A.; Summers, R.J. Characterization of the $\beta$-adrenoceptor subtype involved in mediation of glucose transport in L6 cells. Br. J. Pharmacol. 2002, 137, 9-18. [CrossRef]

326. Nevzorova, J.; Evans, B.A.; Bengtsson, T.; Summers, R.J. Multiple signalling pathways involved in $\beta_{2}$-adrenoceptor-mediated glucose uptake in rat skeletal muscle cells. Br. J. Pharmacol. 2006, 147, 446-454. [CrossRef] 
327. McConville, P.; Lakatta, E.G.; Spencer, R.G. Greater glycogen utilization during $\beta_{1}$ - than $\beta_{2}$-adrenergic receptor stimulation in the isolated perfused rat heart. Am. J. Physiol. Endocrinol. Metab. 2007, 293, E1828-E1835. [CrossRef] [PubMed]

328. Andres, D.A.; Young, L.E.A.; Veeranki, S.; Hawkinson, T.R.; Levitan, B.M.; He, D.; Wang, C.; Satin, J.; Sun, R.C. Improved workflow for mass spectrometry-based metabolomics analysis of the heart. J. Biol. Chem. 2020, 295, 2676-2686. [CrossRef] [PubMed]

329. McConville, P.; Spencer, R.G.; Lakatta, E.G. Temporal dynamics of inotropic, chronotropic, and metabolic responses during $\beta_{1}$ and $\beta_{2}$-AR stimulation in the isolated, perfused rat heart. Am. J. Physiol. Endocrinol. Metab. 2005, 289, E412-E418. [CrossRef]

330. Ahmad, T.; Miller, P.E.; McCullough, M.; Desai, N.R.; Riello, R.; Psotka, M.; Böhm, M.; Allen, L.A.; Teerlink, J.R.; Rosano, G.; et al. Why has positive inotropy failed in chronic heart failure? Lessons from prior inotrope trials. Eur. J. Heart Fail. 2019, 21, 1064-1078. [CrossRef] [PubMed]

331. Lafontan, M.; Berlan, M. Fat cell adrenergic receptors and the control of white and brown fat cell function. J. Lipid Res. 1993, 34, 1057-1091. [CrossRef]

332. Zhao, J.; Cannon, B.; Nedergaard, J. Thermogenesis is $\beta_{3}$ - but not $\beta_{1}$-adrenergically mediated in rat brown fat cells, even after cold acclimation. Am. J. Physiol. 1998, 275, R2002-R2011. [CrossRef]

333. Barr, L.A.; Lambert, J.P.; Shimizu, Y.; Barouch, L.A.; Naqvi, N.; Calvert, J.W. Exercise training provides cardioprotection by activating and coupling endothelial nitric oxide synthase via a $\beta_{3}$-adrenergic receptor-AMP-activated protein kinase signaling pathway. Med. Gas. Res. 2017, 7, 1-8.

334. Moniotte, S.; Kobzik, L.; Feron, O.; Trochu, J.N.; Gauthier, C.; Balligand, J.L. Upregulation of $\beta_{3}$-adrenoceptors and altered contractile response to inotropic amines in human failing myocardium. Circulation 2001, 103, 1649-1655. [CrossRef]

335. Cheng, H.J.; Zhang, Z.S.; Onishi, K.; Ukai, T.; Sane, D.C.; Cheng, C.P. Upregulation of functional $\beta_{3}$-adrenergic receptor in the failing canine myocardium. Circ. Res. 2001, 89, 599-606. [CrossRef]

336. Treskatsch, S.; Feldheiser, A.; Rosin, A.T.; Sifringer, M.; Habazettl, H.; Mousa, S.A.; Shakibaei, M.; Schäfer, M.; Spies, C.D. A modified approach to induce predictable congestive heart failure by volume overload in rats. PLoS ONE 2014,9 , e87531.

337. Kawaguchi, S.; Okada, M.; Ijiri, E.; Koga, D.; Watanabe, T.; Hayashi, K.; Kashiwagi, Y.; Fujita, S.; Hasebe, N. $\beta_{3}$-Adrenergic receptor blockade reduces mortality in endotoxin-induced heart failure by suppressing induced nitric oxide synthase and saving cardiac metabolism. Am. J. Physiol. Heart Circ. Physiol. 2020, 318, H283-H294. [CrossRef] [PubMed]

338. Ziskoven, C.; Grafweg, S.; Bolck, B.; Wiesner, R.J.; Jimenez, M.; Giacobino, J.P.; Bloch, W.; Schwinger, R.H.; Brixius, K. Increased $\mathrm{Ca}^{2+}$ sensitivity and protein expression of SERCA 2a in situations of chronic $\beta_{3}$-adrenoceptor deficiency. Pflugers. Arch. 2007, 453, 443-453. [CrossRef] [PubMed]

339. Moens, A.L.; Leyton-Mange, J.S.; Niu, X.; Yang, R.; Cingolani, O.; Arkenbout, E.K.; Champion, H.C.; Bedja, D.; Gabrielson, K.L.; Chen, J.; et al. Adverse ventricular remodeling and exacerbated NOS uncoupling from pressure-overload in mice lacking the $\beta_{3}$-adrenoreceptor. J. Mol. Cell. Cardiol. 2009, 47, 576-585. [CrossRef] [PubMed]

340. Aragon, J.P.; Condit, M.E.; Bhushan, S.; Predmore, B.L.; Patel, S.S.; Grinsfelder, D.B.; Gundewar, S.; Jha, S.; Calvert, J.W.; Barouch, L.A.; et al. $\beta_{3}$-adrenoreceptor stimulation ameliorates myocardial ischemia-reperfusion injury via endothelial nitric oxide synthase and neuronal nitric oxide synthase activation. J. Am. Coll. Cardiol. 2011, 58, 2683-2691. [CrossRef] [PubMed]

341. Niu, X.; Watts, V.L.; Cingolani, O.H.; Sivakumaran, V.; Leyton-Mange, J.S.; Ellis, C.L.; Miller, K.L.; Vandegaer, K.; Bedja, D.; Gabrielson, K.L.; et al. Cardioprotective effect of $\beta_{3}$-adrenergic receptor agonism: Role of neuronal nitric oxide synthase. J. Am. Coll. Cardiol. 2012, 59, 1979-1987. [CrossRef]

342. Niu, X.; Zhao, L.; Li, X.; Xue, Y.; Wang, B.; Lv, Z.; Chen, J.; Sun, D.; Zheng, Q. $\beta_{3}$-adrenoreceptor stimulation protects against myocardial infarction injury via eNOS and nNOS activation. PLoS ONE 2014, 9, e98713. [CrossRef]

343. Belge, C.; Hammond, J.; Dubois-Deruy, E.; Manoury, B.; Hamelet, J.; Beauloye, C.; Markl, A.; Pouleur, A.C.; Bertrand, L.; Esfahani, $\mathrm{H}$; et al. Enhanced expression of $\beta_{3}$-adrenoceptors in cardiac myocytes attenuates neurohormone-induced hypertrophic remodeling through nitric oxide synthase. Circulation 2014, 129, 451-462. [CrossRef] [PubMed]

344. Trappanese, D.M.; Liu, Y.; McCormick, R.C.; Cannavo, A.; Nanayakkara, G.; Baskharoun, M.M.; Jarrett, H.; Woitek, F.J.; Tillson, D.M.; Dillon, A.R.; et al. Chronic $\beta_{1}$-adrenergic blockade enhances myocardial $\beta_{3}$-adrenergic coupling with nitric oxide-cGMP signaling in a canine model of chronic volume overload: New insight into mechanisms of cardiac benefit with selective $\beta_{1}$-blocker therapy. Basic Res. Cardiol. 2015, 110, 456. [CrossRef]

345. Kamiya, M.; Asai, K.; Maejima, Y.; Shirakabe, A.; Murai, K.; Noma, S.; Komiyama, H.; Sato, N.; Mizuno, K.; Shimizu, W. $\beta_{3}$-adrenergic receptor agonist prevents diastolic dysfunction in an angiotensin II-induced cardiomyopathy mouse model. J. Pharmacol. Exp. Ther. 2021, 376, 473-481. [CrossRef] [PubMed]

346. Finlin, B.S.; Memetimin, H.; Zhu, B.; Confides, A.L.; Vekaria, H.J.; El Khouli, R.H.; Johnson, Z.R.; Westgate, P.M.; Chen, J.; Morris, A.J.; et al. The $\beta_{3}$-adrenergic receptor agonist mirabegron improves glucose homeostasis in obese humans. J. Clin. Investig. 2020, 130, 2319-2331. [CrossRef] [PubMed]

347. Dehvari, N.; Sato, M.; Bokhari, M.H.; Kalinovich, A.; Ham, S.; Gao, J.; Nguyen, H.; Whiting, L.; Mukaida, S.; Merlin, J.; et al. The metabolic effects of mirabegron are mediated primarily by $\beta_{3}$-adrenoceptors. Pharmacol. Res. Perspect. 2020, 8, e00643. [CrossRef]

348. Smith, S.A.; Levy, A.L.; Sennitt, M.V.; Simson, D.L.; Cawthorne, M.A. Effects of BRL 26830, a novel $\beta$-adrenoceptor agonist, on glucose tolerance, insulin sensitivity and glucose turnover in Zucker (fa/fa) rats. Biochem. Pharmacol. 1985, 34, $2425-2429$. [CrossRef] 
349. Williams, C.A.; Shih, M.F.; Taberner, P.V. Sustained improvement in glucose homeostasis in lean and obese mice following chronic administration of the $\beta_{3}$ agonist SR 58611A. Br. J. Pharmacol. 1999, 128, 1586-1592. [CrossRef] [PubMed]

350. Cawthorne, M.A.; Carroll, M.J.; Levy, A.L.; Lister, C.A.; Sennitt, M.V.; Smith, S.A.; Young, P. Effects of novel $\beta$-adrenoceptor agonists on carbohydrate metabolism: Relevance for the treatment of non-insulin-dependent diabetes. Int. J. Obes. 1984, 8, 93-102.

351. Hao, L.; Scott, S.; Abbasi, M.; Zu, Y.; Khan, M.S.H.; Yang, Y.; Wu, D.; Zhao, L.; Wang, S. Beneficial Metabolic Effects of Mirabegron In Vitro and in High-Fat Diet-Induced Obese Mice. J. Pharmacol. Exp. Ther. 2019, 369, 419-427. [CrossRef]

352. Wang, Z.H.; Li, Y.F.; Guo, Y.Q. $\beta_{3}$-Adrenoceptor activation attenuates atherosclerotic plaque formation in ApoE ${ }^{-/-} \mathrm{mice}$ through lowering blood lipids and glucose. Acta. Pharmacol. Sin. 2013, 34, 1156-1163. [CrossRef]

353. Shi, S.T.; Li, Y.F.; Guo, Y.Q.; Wang, Z.H. Effect of $\beta_{3}$-adrenoceptor stimulation on the levels of ApoA-I, PPAR $\alpha$, and PPAR $\gamma$ in apolipoprotein E-deficient mice. J. Cardiovasc. Pharmacol. 2014, 64, 407-411. [CrossRef] [PubMed]

354. Bundgaard, H.; Axelsson, A.; Hartvig Thomsen, J.; Sorgaard, M.; Kofoed, K.F.; Hasselbalch, R.; Fry, N.A.; Valeur, N.; Boesgaard, S.; Gustafsson, F.; et al. The first-in-man randomized trial of a $\beta_{3}$ adrenoceptor agonist in chronic heart failure: The BEAT-HF trial. Eur. J. Heart Fail. 2017, 19, 566-575. [CrossRef] [PubMed]

355. Pouleur, A.C.; Anker, S.; Brito, D.; Brosteanu, O.; Hasenclever, D.; Casadei, B.; Edelmann, F.; Filippatos, G.; Gruson, D.; Ikonomidis, I.; et al. Rationale and design of a multicentre, randomized, placebo-controlled trial of mirabegron, a $\beta_{3}$-adrenergic receptor agonist on left ventricular mass and diastolic function in patients with structural heart disease $\beta_{3}$-left ventricular hypertrophy (b $\left.{ }_{3}-\mathrm{LVH}\right)$. Esc Heart Fail. 2018, 5, 830-841. Erratum in: ESC Heart Fail. 2018, 5, 1199. [CrossRef]

356. Böhm, M.; Maack, C. Treatment of heart failure with b-blockers. Mechanisms and results. Basic Res. Cardiol. 2000, 95, 115-124. [CrossRef] [PubMed]

357. Katz, A.M. Changing strategies in the management of heart failure. J. Am. Coll. Cardiol. 1989, 13, 513-523. [CrossRef]

358. Hwang, I.C. Myocardial Efficiency: A Reliable Load-independent Parameter of Cardiac Performance? J. Cardiovasc. Imaging 2020, 28, 279-282. [CrossRef] [PubMed]

359. Bing, R.J.; Siegel, A.; Ungar, I.; Gilbert, M. Metabolism of the human heart. II. Studies on fat, ketone and amino acid metabolism. Am. J. Med. 1954, 16, 504-515. [CrossRef]

360. Opie, L.H. Effect of $\beta$-adrenergic blockade on biochemical and metabolic response to exercise. Am. J. Cardiol. 1985, 55, 95D-100D. [CrossRef]

361. McLeod, A.A.; Brown, J.E.; Kitchell, B.B.; Sedor, F.A.; Kuhn, C.; Shand, D.G.; Williams, R.S. Hemodynamic and metabolic responses to exercise after adrenoceptor blockade in humans. J. Appl. Physiol. Respir. Environ. Exerc. Physiol. 1984, 56, 716-722. [CrossRef]

362. Verstappen, F.T.; van Baak, M.A. Exercise capacity, energy metabolism, and $\beta$-adrenoceptor blockade. Comparison between a $\beta_{1}$-selective and a non-selective $\beta$ blocker. Eur. J. Appl. Physiol. Occup. Physiol. 1987, 56, 712-718. [CrossRef]

363. Hansen, O.; Johansson, B.W.; Nilsson-Ehle, P. Metabolic, electrocardiographic, and hemodynamic responses to increased circulating adrenaline: Effects of selective and nonselective $\beta$-adrenoceptor blockade. Angiology 1990, 41, 175-188. [CrossRef]

364. Sarafidis, P.A.; Bakris, G.L. Antihypertensive treatment with $\beta$-blockers and the spectrum of glycaemic control. QJM 2006, 99 , 431-436. [CrossRef] [PubMed]

365. Deacon, S.P. The effects of atenolol and propranolol upon lipolysis. Br. J. Clin. Pharmacol. 1978, 5, 123-125. [CrossRef] [PubMed]

366. Zmudka, K.; Dubiel, J.; Pieniazek, P.; Dudek, D.; Kocurek, A.; Trebacz, J.; Grodecki, J.; Flameng, W.; de Geest, H. Influence of an early adrenergic blockade on thrombotic infarct size and myocardial metabolism. J. Physiol. Pharmacol. 1998, 49, 333-352. [PubMed]

367. Panchal, A.R.; Stanley, W.C.; Kerner, J.; Sabbah, H.N. $\beta$-receptor blockade decreases carnitine palmitoyl transferase I activity in dogs with heart failure. J. Card. Fail. 1998, 4, 121-126. [CrossRef]

368. Igarashi, N.; Nozawa, T.; Fujii, N.; Suzuki, T.; Matsuki, A.; Nakadate, T.; Igawa, A.; Inoue, H. Influence of $\beta$-adrenoceptor blockade on the myocardial accumulation of fatty acid tracer and its intracellular metabolism in the heart after ischemia-reperfusion injury. Circ. J. 2006, 70, 1509-1514. [CrossRef]

369. Wallhaus, T.R.; Taylor, M.; DeGrado, T.R.; Russell, D.C.; Stanko, P.; Nickles, R.J.; Stone, C.K. Myocardial free fatty acid and glucose use after carvedilol treatment in patients with congestive heart failure. Circulation 2001, 103, 2441-2446. [CrossRef]

370. Sharma, V.; Dhillon, P.; Wambolt, R.; Parsons, H.; Brownsey, R.; Allard, M.F.; McNeill, J.H. Metoprolol improves cardiac function and modulates cardiac metabolism in the streptozotocin-diabetic rat. Am. J. Physiol. Heart Circ. Physiol. 2008, 294, H1609-H1620. [CrossRef]

371. Bøttcher, M.; Refsgaard, J.; Gøtzsche, O.; Andreasen, F.; Nielsen, T.T. Effect of carvedilol on microcirculatory and glucose metabolic regulation in patients with congestive heart failure secondary to ischemic cardiomyopathy. Am. J. Cardiol. 2002, 89, 1388-1393. [CrossRef]

372. Podbregar, M.; Voga, G. Effect of selective and nonselective $\beta$-blockers on resting energy production rate and total body substrate utilization in chronic heart failure. J. Card Fail. 2002, 8, 369-378. [CrossRef]

373. Bakris, G.L.; Fonseca, V.; Katholi, R.E.; McGill, J.B.; Messerki, F.H.; Phillips, R.A.; Raskin, P.; Wright, J.T., Jr.; Oakes, R.; Lukas, M.A.; et al. Metabolic effects of carvedilol vs metoprolol in patients with type 2 diabetes mellitus and hypertension A randomized controlled trial. J. Am. Med. Assoc. 2004, 292, 2227-2236. [CrossRef] 
374. Al-Hesayen, A.; Azevedo, E.R.; Floras, J.S.; Hollingshead, S.; Lopaschuk, G.D.; Parker, J.D. Selective versus nonselective $\beta$ adrenergic receptor blockade in chronic heart failure: Differential effects on myocardial energy substrate utilization. Eur. J. Heart Fail 2005, 7, 618-623. [CrossRef] [PubMed]

375. Basat, O.; Ucak, S.; Seber, S.; Oztekin, E.; Altuntas, Y. After myocardial infarction carvedilol improves insulin resistance compared to metoprolol. Clin. Res. Cardiol. 2006, 95, 99-104. [CrossRef] [PubMed]

376. Fonseca, V.A. Effects of $\beta$-blockers on glucose and lipid metabolism. Curr. Med. Res. Opin. 2010, 26, 615-629. [CrossRef]

377. De Peuter, O.R.; Verberne, H.J.; Kok, W.E.; van den Bogaard, B.; Schaap, M.; Nieuwland, R.; Meijers, J.C.; Somsen, G.A.; Bakx, A.; Kamphuisen, P.W. Differential effects of nonselective versus selective $\beta$-blockers on cardiac sympathetic activity and hemostasis in patients with heart failure. J. Nucl. Med. 2013, 54, 1733-1739. [CrossRef] [PubMed]

378. Järvisalo, J.O.; Saris, N.-E.L. Action of propranolol on mitochondrial functions-Effects on energized ion fluxes in the presence of valinomycin. Biochem. Pharmacol. 1975, 24, 1701-1705.

379. Komai, H.; Berkoff, H.A. Effects of quinidine and propranolol on energy transduction in beef heart mitochondria. Biochem. Pharmacol. 1979, 28, 1501-1504. [CrossRef]

380. Bhayana, V.; Alto, L.E.; Dhalla, N.S. The effects of $\beta$-adrenergic receptor blockers on heart mitochondrial metabolism. Gen. Pharmacol. Vasc. System. 1980, 11, 271-274. [CrossRef]

381. Kametani, R.; Miura, T.; Harada, N.; Shibuya, M.; Wang, R.; Tan, H.; Fukagawa, Y.; Kawamura, S.; Matsuzaki, M. Carvedilol inhibits mitochondrial oxygen consumption and superoxide production during calcium overload in isolated heart mitochondria Circ. J. 2006, 70, 321-326. [CrossRef] [PubMed]

382. Goldhammer, E.; Maor, I.; Shnitzer, S.; Lanir, A.; Abinader, E.G. The early antioxidant effect of carvedilol predicts the clinical course in congestive heart failure patients. J. Cardiovasc. Med. 2007, 8, 453-456. [CrossRef]

383. Noack, E.; Greeff, K. Inhibition of calcium transport in mitochondria by -receptor blocking substances and its reactivation by phospholipids. Experientia 1971, 27, 810-811. [CrossRef]

384. Dhalla, N.S.; Lee, S.L. Comparison of the actions of acebutolol, practolol and propranolol on calcium transport by heart microsomes and mitochondria. Br. J. Pharmac. 1976, 57, 215-221. [CrossRef] [PubMed]

385. Palaniyandi, S.S.; Qi, X.; Yogalingam, G.; Ferreira, J.C.B.; Mochly-Rosen, D. Regulation of mitochondrial processes: A target for heart failure. Drug Discov. Today Dis. Mech. 2010, 7, 1-14. [CrossRef]

386. Brown, D.A.; Perry, J.B.; Allen, M.E.; Sabbah, H.N.; Stauffer, B.L.; Shaikh, S.R.; Cleland, J.G.; Colucci, W.S.; Butler, J.; Voors, A.A.; et al. Expert consensus document: Mitochondrial function as a therapeutic target in heart failure. Nat. Rev. Cardiol. 2017, 14, 238-250. [CrossRef] [PubMed]

387. Staudt, A.; Mobini, R.; Fu, M.; Grosse, Y.; Stangl, V.; Stangl, K.; Thiele, A.; Baumann, G.; Felix, S.B. $\beta_{1}$-Adrenoceptor antibodies induce positive inotropic response in isolated cardiomyocytes. Eur. J. Pharmacol. 2001, 423, 115-119. [CrossRef]

388. Wallukat, G.; Müller, J.; Podlowski, S.; Nissen, E.; Morwinski, R.; Hetzer, R. Agonist-like $\beta$-adrenoceptor antibodies in heart failure. Am. J. Cardiol. 1999, 83, 75H-79H. [CrossRef]

389. Magnusson, Y.; Wallukat, G.; Waagstein, F.; Hjalmarson, A.; Hoebeke, J. Autoimmunity in idiopathic dilated cardiomyopathy. Characterization of antibodies against the $\beta_{1}$-adrenoceptor with positive chronotropic effect. Circulation 1994, 89, $2760-2767$. [CrossRef] [PubMed]

390. Staudt, Y.; Mobini, R.; Fu, M.; Felix, S.B.; Kühn, J.P.; Staudt, A. $\beta_{1}$-adrenoceptor antibodies induce apoptosis in adult isolated cardiomyocytes. Eur. J. Pharmacol. 2003, 466, 1-6. [CrossRef]

391. Shi, L.; Liu, J.; Zhang, Y.; Chen, M.; Liu, J. $\beta_{1}$-adrenoceptor antibodies induce myocardial apoptosis via inhibiting PGC- $1 \alpha$-related pathway. BMC Cardiovasc. Disord. 2020, 20, 269. [CrossRef]

392. Wen, J.; Wang, J.; Li, P.; Wang, R.; Wang, J.; Zhou, X.; Zhang, L.; Li, H.; Wei, S.; Cai, H.; et al. Protective effects of higenamine combined with (6)-gingerol against doxorubicin-induced mitochondrial dysfunction and toxicity in H9c2 cells and potential mechanisms. Biomed. Pharmacother. 2019, 115, 108881. [CrossRef]

393. Cadenas, E.; Davies, K.J. Mitochondrial free radical generation, oxidative stress, and aging. Free Radic. Biol. Med. 2000, $29,222-230$. [CrossRef]

394. Jiang, Q.; Yin, J.; Chen, J.; Ma, X.; Wu, M.; Liu, G.; Yao, K.; Tan, B.; Yin, Y. Mitochondria-Targeted Antioxidants: A Step towards Disease Treatment. Oxidative Med. Cell. Longev. 2020, 8837893. [CrossRef]

395. Kiyuna, L.A.; Albuquerque, R.P.E.; Chen, C.H.; Mochly-Rosen, D.; Ferreira, J.C.B. Targeting mitochondrial dysfunction and oxidative stress in heart failure: Challenges and opportunities. Free Radic. Biol. Med. 2018, 129, 155-168. [CrossRef]

396. Eichhorn, E.J.; Bedotto, J.B.; Malloy, C.R.; Hatfield, B.A.; Deitchman, D.; Brown, M.; Willard, J.E.; Grayburn, P.A. Effect of $\beta$-adrenergic blockade on myocardial function and energetics in congestive heart failure. Improvements in hemodynamic, contractile, and diastolic performance with bucindolol. Circulation 1990, 82, 473-483. [CrossRef] [PubMed]

397. Eichhorn, E.J.; Heesch, C.M.; Barnett, J.H.; Alvarez, L.G.; Fass, S.M.; Grayburn, P.A.; Hatfield, B.A.; Marcoux, L.G.; Malloy, C.R. Effect of metoprolol on myocardial function and energetics in patients with nonischemic dilated cardiomyopathy A randomized, double-blind, placebo-controlled study. J. Am. Coll. Cardiol. 1994, 24, 1310-1320. [CrossRef]

398. Andersson, B.; Lomsky, M.; Waagstein, F. The link between acute haemodynamic adrenergic beta-blockade and long-term effects in patients with heart failure. A study on diastolic function, heart rate and myocardial metabolism following intravenous metoprolol. Eur. Heart J. 1993, 14, 1375-1385. [CrossRef] 
399. Galie, N.; Branzi, A.; Magnani, G.; Melandri, G.; Caldarera, I.; Rapezzi, C.; Grattoni, C.; Magnani, B. Effect of enoximone alone and in combination with metoprolol on myocardial function and energetics in severe congestive heart failure: Improvement in hemodynamic and metabolic profile. Cardiovasc. Drugs Ther. 1993, 7, 337-347. [CrossRef] [PubMed]

400. Beanlands, R.S.; Nahmias, C.; Gordon, E.; Coates, G.; de Kemp, R.; Firnau, G.; Fallen, E. The effects of $\beta_{1}$-blockade on oxidative metabolism and the metabolic cost of ventricular work in patients with left ventricular dysfunction: A double-blind, placebocontrolled, positron-emission tomography study. Circulation 2000, 102, 2070-2075. [CrossRef]

401. Sanchez-Roman, I.; Gomez, J.; Naudi, A.; Ayala, V.; Portero-Otín, M.; Lopez-Torres, M.; Pamplona, R.; Barja, G. The $\beta$-blocker atenolol lowers the longevity-related degree of fatty acid unsaturation, decreases protein oxidative damage and increases ERK signaling in the heart of C57BL/ 6 mice. Rejuvenation Res. 2010, 13, 683-693. [CrossRef]

402. Gómez, A.; Sánchez-Roman, I.; Gomez, J.; Cruces, J.; Mate, I.; Lopez-Torres, M.; Naudi, A.; Portero-Otin, M.; Pamplona, R.; De la Fuente, M.; et al. Lifelong treatment with atenolol decreases membrane fatty acid unsaturation and oxidative stress in heart and skeletal muscle mitochondria and improves immunity and behavior, without changing mice longevity. Aging Cell. 2014, 13, 551-560. [CrossRef]

403. Yoshikawa, T.; Port, J.D.; Asano, K.; Chidiak, P.; Bouvier, M.; Dutcher, D.; Roden, R.L.; Minobe, W.; Tremmel, K.D.; Bristow, M.R. Cardiac adrenergic receptor effects of carvedilol. Eur. Heart J. 1996, 17, 8-16. [CrossRef]

404. ALLHAT Collaborative Research Group. Major cardiovascular events in hypertensive patients randomized to doxazosin vs chlorthalidone: The antihypertensive and lipid-lowering treatment to prevent heart attack trial (ALLHAT). JAMA 2000, 283, 1967-1975. [CrossRef]

405. Molenaar, P.; Christ, T.; Ravens, U.; Kaumann, A. Carvedilol blocks $\beta_{2}$ - more than $\beta_{1}$-adrenoceptors in human heart. Cardiovasc. Res. 2006, 69, 128-139. [CrossRef] [PubMed]

406. Molenaar, P.; Christ, T.; Berk, E.; Engel, A.; Gillette, K.T.; Galindo-Tovar, A.; Ravens, U.; Kaumann, A.J. Carvedilol induces greater control of $\beta_{2}$ - than $\beta_{1}$-adrenoceptor-mediated inotropic and lusitropic effects by PDE3, while PDE4 has no effect in human failing myocardium. Naunyn. Schmiedebergs. Arch. Pharmacol. 2014, 387, 629-640. [CrossRef] [PubMed]

407. Koshimizu, T.A.; Tsujimoto, G.; Hirasawa, A.; Kitagawa, Y.; Tanoue, A. Carvedilol selectively inhibits oscillatory intracellular calcium changes evoked by human $\alpha_{1 D^{-}}$and $\alpha_{1 \mathrm{~B}}$-adrenergic receptors. Cardiovasc. Res. 2004, 63, 662-672. [CrossRef] [PubMed]

408. Iaccarino, G.; Keys, J.R.; Rapacciuolo, A.; Shotwell, K.F.; Lefkowitz, R.J.; Rockman, H.A.; Koch, W.J. Regulation of myocardial $\beta$ ARK1 expression in catecholamine-induced cardiac hypertrophy in transgenic mice overexpressing $\alpha_{1 B}$-adrenergic receptors. J. Am. Coll. Cardiol. 2001, 38, 534-540. [CrossRef]

409. Kukin, M.L.; Kalman, J.; Charney, R.H.; Levy, D.K.; Buchholz-Varley, C.; Ocampo, O.N.; Eng, C. Prospective, randomized comparison of effect of long-term treatment with metoprolol or carvedilol on symptoms, exercise, ejection fraction, and oxidative stress in heart failure. Circulation 1999, 99, 2645-2651. [CrossRef]

410. Lysko, P.G.; Webb, C.L.; Gu, J.L.; Ohlstein, E.H.; Ruffolo, R.R., Jr.; Yue, T.L. A comparison of carvedilol and metoprolol antioxidant activities in vitro. J. Cardiovasc. Pharmacol. 2000, 36, 277-281. [CrossRef]

411. Arumanayagam, M.; Chan, S.; Tong, S.; Sanderson, J.E. Antioxidant properties of carvedilol and metoprolol in heart failure: A double-blind randomized controlled trial. J. Cardiovasc. Pharmacol. 2001, 37, 48-54. [CrossRef]

412. Yasunari, K.; Maeda, K.; Nakamura, M.; Watanabe, T.; Yoshikawa, J.; Asada, A. Effects of carvedilol on oxidative stress in polymorphonuclear and mononuclear cells in patients with essential hypertension. Am. J. Med. 2004, 116, 460-465. [CrossRef]

413. Kveiborg, B.; Christiansen, B.; Major-Petersen, A.; Torp-Pedersen, C. Metabolic Effects of $\beta$-Adrenoceptor Antagonists with Special Emphasis on Carvedilol. Am. J. Cardiovasc. Drugs 2006, 6, 209-217. [CrossRef] [PubMed]

414. Yao, A.; Kohmoto, O.; Oyama, T.; Sugishita, Y.; Shimizu, T.; Harada, K.; Matsui, H.; Komuro, I.; Nagai, R.; Matsuo, H.; et al. Characteristic effects of $\alpha_{1}-\beta_{1,2}$-adrenergic blocking agent, carvedilol, on $\left[\mathrm{Ca}^{2+}\right] \mathrm{i}$ in ventricular myocytes compared with those of timolol and atenolol. Circ. J. 2003, 67, 83-90. [CrossRef]

415. Heesch, C.; Marcoux, L.; Hatfield, B.; Eichhorn, E.J. Hemodynamic and energetic comparison of carvedilol and metoprolol for the treatment of congestive heart failure. Am. J. Cardiol. 1995, 75, 360-364. [CrossRef]

416. Onay-Besikci, A.; Suzmecelik, E.; Ozcelikay, A.T. Carvedilol suppresses fatty acid oxidation and stimulates glycolysis in C2C12 cells. Can. J. Physiol. Pharmacol. 2012, 90, 1087-1093. [CrossRef] [PubMed]

417. Toda, N. Vasodilating $\beta$-adrenoceptor blockers as cardiovascular therapeutics. Pharmacol. Ther. 2003, 100, 215-234. [CrossRef]

418. Grandinetti, V.; Carlos, F.P.; Antonio, E.L.; de Oliveira, H.A.; Dos Santos, L.; Yoshizaki, A.; Mansano, B.; Silva, F.A.; Porte, L.A.; Albuquerque-Pontes, G.M.; et al. Photobiomodulation therapy combined with carvedilol attenuates post-infarction heart failure by suppressing excessive inflammation and oxidative stress in rats. Sci. Rep. 2019, 9, 9425. [CrossRef] [PubMed]

419. Toyoda, S.; Haruyama, A.; Inami, S.; Arikawa, T.; Saito, F.; Watanabe, R.; Sakuma, M.; Abe, S.; Nakajima, T.; Tanaka, A.; et al. Effects of carvedilol vs bisoprolol on inflammation and oxidative stress in patients with chronic heart failure. J. Cardiol. 2020, 75, 140-147. [CrossRef]

420. Gomes, K.M.; Bechara, L.R.; Lima, V.M.; Ribeiro, M.A.; Campos, J.C.; Dourado, P.M.; Kowaltowski, A.J.; Mochly-Rosen, D.; Ferreira, J.C. Aldehydic load and aldehyde dehydrogenase 2 profile during the progression of post-myocardial infarction cardiomyopathy: Benefits of Alda. Int. J. Cardiol. 2015, 179, 129-138. [CrossRef]

421. Jacob, S.; Rett, K.; Wicklmayr, M.; Agrawal, B.; Augustin, H.J.; Dietze, G.J. Differential effect of chronic treatment with two b-blocking agents on insulin sensitivity: The carvedilol-metoprolol study. J. Hypertens. 1996, 14, 489-494. [CrossRef] 
422. Giugliano, D.; Acampora, R.; Marfella, R.; De Rosa, N.; Ziccardi, P.; Ragone, R.; De Angelis, L.; D'Onofrio, F. Metabolic and cardiovascular effects of carvedilol and atenolol in non-insulin-dependent diabetes mellitus and hypertension. A randomized, controlled trial. Ann. Intern. Med. 1997, 126, 955-959. [CrossRef]

423. Scolletta, S.; Biagioli, B. Energetic myocardial metabolism and oxidative stress: Let's make them our friends in the fight against heart failure. Biomed. Pharmacother. 2010, 64, 203-207. [CrossRef] [PubMed]

424. Beadle, R.M.; Frenneaux, M. Modification of myocardial substrate utilization: A new therapeutic paradigm in cardiovascular disease. Heart 2010, 96, 824-830. [CrossRef] [PubMed]

425. Hu, H.; Li, X.; Ren, D.; Tan, Y.; Chen, J.; Yang, L.; Chen, R.; Li, J.; Zhu, P. The cardioprotective effects of carvedilol on ischemia and reperfusion injury by AMPK signaling pathway. Biomed. Pharmacother. 2019, 117, 109106. [CrossRef]

426. Chabowski, A.; Momken, I.; Coort, S.L.; Calles-Escandon, J.; Tandon, N.N.; Glatz, J.F.; Luiken, J.J.; Bonen, A. Prolonged AMPK activation increases the expression of fatty acid transporters in cardiac myocytes and perfused hearts. Mol. Cell Biochem. 2006, 288, 201-212. [CrossRef] [PubMed]

427. Kudo, N.; Barr, A.J.; Barr, R.L.; Desai, S.; Lopaschuk, G.D. High rates of fatty acid oxidation during reperfusion of ischemic hearts are associated with a decrease in malonyl-CoA levels due to an increase in 5'-AMP-activated protein kinase inhibition of acetyl-CoA carboxylase. J. Biol. Chem. 1995, 270, 17513-17520. [CrossRef] [PubMed]

428. An, D.; Kewalramani, G.; Qi, D.; Pulinilkunnil, T.; Ghosh, S.; Abrahani, A.; Wambolt, R.; Allard, M.; Innis, S.M.; Rodrigues, B. $\beta$-Agonist stimulation produces changes in cardiac AMPK and coronary lumen LPL only during increased workload. Am. $J$. Physiol. Endocrinol. Metab. 2005, 288, E1120-E1127. [CrossRef]

429. Bussey, C.T.; Thaung, H.P.A.; Hughes, G.; Bahn, A.; Lamberts, R.R. Cardiac b-adrenergic responsiveness of obese Zucker rats: The role of AMPK. Exp. Physiol. 2018, 103, 1067-1075. [CrossRef]

430. Wang, J.; Song, Y.; Li, H.; Shen, Q.; Shen, J.; An, X.; Wu, J.; Zhang, J.; Wu, Y.; Xiao, H.; et al. Exacerbated cardiac fibrosis induced by $\beta$-adrenergic activation in old mice due to decreased AMPK activity. Clin. Exp. Pharmacol. Physiol. 2016, 43, 1029-1037. [CrossRef]

431. Dubois-Deruy, E.; Gelinas, R.; Beauloye, C.; Esfahani, H.; Michel, L.Y.M.; Dessy, C.; Bertrand, L.; Balligand, J.L. $\beta_{3}$-adrenoreceptors protect from hypertrophic remodelling through AMP-activated protein kinase and autophagy. Esc. Heart Fail 2020, 7, $920-932$. [CrossRef] 